University of Texas Rio Grande Valley

ScholarWorks @ UTRGV

Management Faculty Publications and

Presentations

Robert C. Vackar College of Business \& Entrepreneurship

$5-30-2019$

\title{
Strategic Agility, Business Model Innovation and Firm Performance: An Empirical Investigation
}

\author{
Thomas Clauss \\ Michael A. Abebe \\ The University of Texas Rio Grande Valley, michael.abebe@utrgv.edu \\ Chanchai Tangpong \\ Marianne Hock
}

Follow this and additional works at: https://scholarworks.utrgv.edu/mgmt_fac

Part of the Business Administration, Management, and Operations Commons

\section{Recommended Citation}

Clauss, T., Abebe, M., Tangpong, C., \& Hock, M. (2019). Strategic Agility, Business Model Innovation, and Firm Performance: An Empirical Investigation. IEEE Transactions on Engineering Management, 1-18. https://doi.org/10.1109/TEM.2019.2910381

This Article is brought to you for free and open access by the Robert C. Vackar College of Business \& Entrepreneurship at ScholarWorks @ UTRGV. It has been accepted for inclusion in Management Faculty Publications and Presentations by an authorized administrator of ScholarWorks @ UTRGV. For more information, please contact justin.white@utrgv.edu,william.flores01@utrgv.edu. 
This manuscript is the accepted version of the following article: Clauss, T., Abebe, M., Tangpong, C., Hock, M. (in press), Strategic Agility, Business Model Innovation and Firm Performance: An Empirical Investigation, IEEE Transactions on Engineering Management, which will be published in final form soon. This article may be used for non-commercial purposes in accordance with IEEEs' Terms and Conditions for Self-Archiving.

\title{
Strategic Agility, Business Model Innovation and Firm Performance: An Empirical Investigation
}

\author{
Thomas Clauss (Corresponding author) \\ Philipps-University of Marburg (clausst@uni-marburg.de)
}

\section{Michael Abebe}

University of Texas Rio Grande Valley

\section{Chanchai Tangpong}

North Dakota State University

\section{Marianne Hock}

Philipps-University of Marburg

\begin{abstract}
Despite the robust literature on the nature of business models and their implications for firm performance, research on the organizational antecedents of business model innovations (BMIs) is still evolving. In this study, we empirically examine the extent to which firm-level strategic agility predicts the adoption of three (value creation, value capture and value proposition) types of BMIs. Furthermore, we propose that the relationship between firm-level strategic agility and BMI adoption is contingent on the degree of environmental turbulence. Finally, we explore the mediating role that BMI plays in the relationship between firm-level strategic agility and firm performance. Our analysis of data from 432 German firms in the electronics industry indicates that strategic agility is positively related to BMI and that this relationship is indeed strengthened by the degree of environmental turbulence. Additionally, our findings show that, while value proposition and value creation BMIs have positive relationships with firm performance, value capture innovation was negatively related to firm performance; these findings were
\end{abstract}


contrary to our prediction. Finally, the results of our mediation tests indicate that BMI serves as an important intermediary mechanism through which firms’ strategic agility contributes to superior firm performance.

\section{Managerial Relevance}

Our study significantly contributes to managerial knowledge in three interrelated ways: First, we demonstrate that firms should develop their firm’s capabilities toward strategic agility (i.e., strategic sensitivity, leadership unity, and resource fluidity) in order to pave important foundations for subsequent business model innovation. Second, we show that the link between strategic agility and firm performance is mediated by business model innovation. Therefore, business model innovation might be a necessary mechanism to utilize firm-level capabilities, Third, we show that business model innovation might also have a dark side, as some business model innovation efforts might even reduce firm performance. Therefore, our study demonstrates that utilizing business model innovation is not universally beneficial and should be handled with care. Based on interviews with managers, we show that changes in the business model and in particular value capture innovation requires systemic adaptations of the organization to prevent issues related to local optimization.

Keywords: Business model innovation, value creation, value capture, value proposition, strategic agility, dynamic capabilities, strategic sensitivity, leadership unity, resource fluidity, partial least squares

\section{INTRODUCTION}

Business model innovation (BMI) has developed over the last couple of decades into an important area of inquiry in the literature of strategic management and innovation [1]. Along with the proliferation of scholarly work, there has also been substantial growth in interest among practitioners due to the increasing realization that BMI can be used a powerful competitive "weapon” in the marketplace [2]. Defined as organizational action in "adding new activities, linking activities in novel ways or changing which party performs an activity” [3, p. 41], BMI creates a competitive advantage for firms by helping them to deliver 
superior value to their customers [3, 4]. Early scholarly works in this area primarily focused on establishing a distinct conceptual boundary for these concepts by clarifying their definitions (i.e., what they are and their dimensions) and distinguishing them from other well-established forms of innovation (e.g., product and process innovations) as distinct but complementary organizational actions [5, p. 1032]. Accordingly, the extensive scholarly work on business model configurations has generated significant insights into the various types of business model architecture and their implications for firms’ product-market strategies. More recent works have been particularly dedicated to understanding the relationship between BMI and firm performance [6, 7].

Despite the significant scholarly insights into the nature of business models and their implications for business strategy and performance, research on the antecedents of BMI is still evolving. Whether and how various managerial and organizational factors influence the adoption of BMIs are still attracting scholarly inquiry. Specifically, there has been limited research on whether and how the firm's strategic agility influences the adoption of BMIs. In the business model context, the applicability of strategic agility to BMI management has so far been limited to the conceptual and anecdotal levels. In this study, we seek to contribute to the ongoing work in this area by investigating the extent to which firm-level strategic agility predicts the adoption of three types (i.e., value creation, value capture and value proposition) of BMIs. We draw on the extensive literature in strategic management to conceptualize firm-level strategic agility consisting of strategic sensitivity, leadership unity and resource fluidity. Specifically, in developing our arguments, we rely on insights from the dynamic capability perspective [8,9] to describe how a firm's ability to recombine and reconfigure its existing resources and capabilities (in our case, strategic agility) facilitates the adoption of BMIs, in turn contributing to higher firm performance [10-12]. Furthermore, we propose that the relationship between firm-level strategic agility and BMI adoption is contingent on the degree of environmental turbulence. More importantly, our study examines the mediating (intermediary) role that BMI adoption plays in the relationship between firm-level strategic agility and firm performance.

This study makes a number of theoretical and empirical contributions to the BMI literature. First, by 
focusing on firm-level strategic agility as an antecedent of BMI adoption, we seek to broaden the scope of business model research that has predominantly focused on the link between BMI adoption and firm performance. Accordingly, by exploring the organizational factors that lead to the adoption of BMIs, we provide scholarly insight into the broader organizational processes and practices that foster the adoption of BMIs. Focusing on firm-level strategic agility allows us to explain why some firms are able to adopt BMIs and others are not and to explore the subsequent performance implications. Second, our study also contributes to the business model literature by proposing and empirically testing an intervening (process) model that explains the impact of firm-level strategic flexibility on firm performance through BMI adoption. Such a process model advances our understanding of the role of business models by empirically showing the mechanism through which firms with high strategic agility achieve superior performance. Our mediation test also provides additional insights into how the adoption of BMIs, facilitated by strategic agility, contributes to higher firm performance. We believe that our emphasis on an intervening (process) model extends the current research in the business model literature, which has mainly focused on the BMIperformance relationship. Third, we also contribute to the literature by connecting strategic agility and business model research, which were, until recently, disparate streams of research [13, 14]. Finally, this study also makes an empirical contribution to the business model literature. Our use of both primary (survey) data and respondent interviews provides us with a richer understanding of the interplay among firm-level strategic agility, BMI and firm performance. Few studies in the business model literature have utilized both quantitative and qualitative data sources to address important research questions. In this regard, we believe that this study contributes to the methodological diversity of business model research, which scholars believe is needed to fully advance knowledge in this area. In the next section, we begin by providing a brief overview of the BMI literature and theoretical work on dynamic capability perspectives.

\section{THEORETICAL BACKGROUND}

\section{A. $\quad$ Business Model and BMI}

Business model research has seen a dramatic increase in scholarly and practitioner attention in recent 
years. As some scholars stated, “[u]nderstanding how business works and how value is created for different stakeholders has become the shibboleth of management scholars in recent years” [15 p. 8]. In line with this statement, the business model literature has attempted to answer the questions of how firms function and how they create value [16]. Over the years, a consensus has emerged among scholars that business models consist of three interrelated dimensions, describing the configuration of how value is proposed, created and captured [17-22]. Value proposition describes the composition of the product/service portfolio and activities regarding new developments and offerings, the firm's role in production or service delivery, and how (i.e., through which channels) and to whom the firm's offerings are made available [20] ${ }^{1}$. Value creation captures the way in which value is generated within the firm as well as externally, together with customers and suppliers [17]. The main question to be answered here is: "What operational processes and resources will be necessary to create the services and products offered?” [25]. The value capture dimension answers the question of how a firm makes money [20]. This dimension considers new cost- and revenue-related decisions, such as margins, quality and prices [23]. Furthermore, capturing value includes the selection and design of adequate revenue streams [4] and revenue models (e.g., razor and blades) [24]. Although these business model dimensions can be considered separately, the heart of a business model lies in its relationships and in the interdependencies of the business model dimensions [6]. The way in which value is created depends upon the configuration of the three dimensions of the business model [20, 26, 27].

Since new contingencies, such as technological advancements, regularly change the conditions for businesses [6, 28], a well-functioning business model does not guarantee enduring market performance and competitive advantage [29]. These changes bring new pressure but also new opportunities to generate value by going beyond the traditional means of value proposition, value creation and value capture [3, 28]. To remain competitive, firms must be able to change and innovate their business model continuously [30]. BMI

\footnotetext{
${ }^{1}$ The value proposition reflects the market side of a business model encompassing decisions or choices regarding offering portfolios, customer/market targets, and delivery channels, and customer relationships [17, 23]. The function of channels has evolved to beyond just the delivery of physical goods, and is critical to the flows of information between firms and their customers [24]. Hence, innovative activities related to delivery channels (e.g., new channels and changes in channel mix, etc.) have also become an important part of the value proposition dimension. When firms change their value proposition, it tends to involve a combination of changes in product/service offerings, market targets, prospective customers, and delivery channels.
} 
can be regarded as a type of organizational innovation [21], which changes the way in which businesses create and capture value for their stakeholders [4]. BMI builds upon changes and reconfigurations of the dimensions of value proposition, value creation, and value capture [19, 31]. As such, BMI can be referred to as being an innovation that complements traditional product and process innovation $[5,18]$. From an operational point of view, BMI refers to reconfiguring existing resources and capabilities and to redesigning nonprofitable routines within the activity system [32].

\section{B. Dynamic Capabilities and Strategic Agility in the Business Model Context}

To better understand the means by which BMI occurs, the recent literature has drawn insights from the dynamic capabilities literature $[30,33]^{2}$. Unlike typical first-order capabilities that focus more on the present approach in converting resources into value proposition, value creation, and value capture, dynamic capabilities are responsible for rearranging and transforming static resources, knowledge, competencies, and existing capabilities into “innovative products and processes" [35 p. 2708]. Whereas dynamic capabilities are primarily related to external changes and significantly depend on environmental uncertainty and volatility, they do not promote continuous change of the organization in "calm" market environments [36]. Since firms, in the context of BMI, may also require the ability to change more proactively yet remain independent from external changes, scholars have introduced the concept of strategic agility. Strategic agility is defined as a firm's ability to renew itself continuously and to maintain flexibility without compromising efficiency $[10,11,36]$. Strategic agility has further been described as the systematic deployment of dynamic capabilities to achieve continuous variations within a firm's product, process and service structures within the business model [11]. While fundamentally built on the concepts of dynamic capability, strategic agility has been conceptualized as a capability that enables firms to be more proactive in changing their organizational systems to gain advantages as part of their intended strategy rather than only reacting to external changes $[37,38]$. Strategic agility enables firms to make rapid changes while

\footnotetext{
${ }^{2}$ Dynamic capabilities “are higher-order capabilities that an organization uses to shape and deploy ("orchestrate”) its resource base to meet the current and anticipated needs of the market” [34, p.25].
} 
preserving their momentum. In other words, strategic agility allows firms to engage in self-renewal and strategic change efforts without environmental changes as the antecedents. This proactive nature of strategic agility makes it slightly, but clearly, distinct from dynamic capabilities, whose purpose is, by nature, more responsive toward external changes, as articulated in the earlier work in the literature [10, 34, 37].

In the business model context, Doz and Kosonen [10] considered strategic agility to be a "keystone to having the ability to transform and renew business models” [10, p.381]. Doz and Kosonen [38] and Doz and Kosonen [10] described three particular capabilities that lay the ground for strategic agility: (1) strategic sensitivity; (2) leadership unity; and (3) resource fluidity. Strategic sensitivity refers to a firm's ability to understand environmental changes and to sense future threats and opportunities for the firm. It is the "sharpness of perception of, and the intensity of awareness and attention to strategic developments" [38 p. 371]. It further includes activities such as scenario planning and forecasting, distancing oneself from one’s own business model to allow for critical evaluation and generating of new alternatives, and gaining an outside-in perspective from external colleagues. Leadership unity refers to the attributes of managerial responsiveness, including making quick and bold decisions, with the support of the entire top management team without the interference of individual political power struggles. In rapidly changing environments, timing is essential. Thus, it is important for a firm's top leaders to cooperate and collectively commit to new and risky projects that foster BMI. To achieve such a commitment requires the efficient distribution of information and constant dialogues that align the roles of the members of the leadership team [10]. New goals should be communicated to all of the leadership members [39], and effective ways of governing communication should be established [40]. A unified commitment toward change can provide the opportunity to modify and create new business models and to discard old ones. Resource fluidity refers to the ability to reconfigure and restructure the resources, knowledge, and capabilities that result in new ways of creating values [10]. Giachetti et al. [41] have identified measures that can be restructured in the short term (operational capabilities) and measures that are difficult to change (structural capabilities), as they are embedded into the structural system. Doz and Kosonen [10] suggested that decoupling/modularizing 
elements and dissociating roles and responsibilities that are deeply seated in the organizational structure can help to reduce the rigidity of the structural capabilities. Resource fluidity is therefore associated with new resource combinations and actual transformations of the dimensions of the business model. Since the recent business model literature has begun to focus on the link between strategic agility and BMI [10, 12], this study contributes to this emerging development by theoretically elaborating and empirically testing the relationships of the three dimensions of strategic agility (i.e., strategic sensitivity, leadership unity, and resource fluidity) and those of BMI (i.e., value proposition, creation, and capture innovations), which in turn shape firm performance. It is also noted that this study is built on the argument for the proactive nature of strategic agility, suggesting that firms can use strategic agility as the basis for their strategic choices, even in the absence of external changes. As such, the scope of this study is focused on the main effect of strategic agility on BMI, which in turn influences firm performance in a manner independent of external changes. This set of relationships is fundamental to our understanding of strategic agility in the business model context. These relationships must first be examined in this study before we further our theoretical development around external changes as a boundary condition of the proposed relationships among strategic agility, BMI, and firm performance.

\section{HYPOTHESIS DEVELOPMENT}

\section{A. Strategic Agility and BMI}

In this study, we conceptualize strategic agility as comprising strategic sensitivity, leadership unity and resource fluidity. Strategic sensitivity is a capability pillar through which a firm garners input from its environment, detects major opportunities in the market, and perceives its internal strengths/constraints relevant to its strategic priorities, market conditions, and current competition [42]. With strategic sensitivity, the firm becomes more aware of new capabilities, technologies, and processes that are needed to create new values for customers or to offer existing values to customers differently. As the firm increases its strategic sensitivity, it will be able to identify the unmet needs in current market conditions as well as the 
environmental changes that create new demands and market opportunities, which are critical to its ability to articulate new value propositions to customers $[11,13]$. Collectively, strategic sensitivity enables the firm to continually reinvent its value propositions to pursue untapped market opportunities and to meet customers' changing needs and preferences over time. Finally, strategic sensitivity enhances the firm's awareness and allows the firm to more effectively assess its cost structures and revenue streams associated with its value propositions and the configuration of its activity systems. Overall, strategic sensitivity is an important determinant of BMI adoption.

Leadership unity, as the second dimension of strategic agility, refers to the extent of managerial commitment present in the firm for continuous organizational adaptation to external environmental changes. The dynamic capability literature has suggested that, once a new opportunity is sensed, a number of managerial decisions (e.g., concerning product architectures, firm boundaries, etc.) are required to effectively incorporate new information into an existing or new business model [8]. As such, leadership unity is critical to the viability of new value propositions [97]. Timely and collective management decisions, propelled by leadership unity, are also critical to structural and operational changes associated with value creation processes, such as new product and service developments or significant improvements in existing products or services [10]. As such, achieving a collective commitment among the firm's top leadership is considered an important element in navigating through changes within the value creation processes [30]. Leadership unity plays an important role in mitigating internal political problems, championing new cost/revenue models, and enabling the firm to embrace new BMIs.

The final dimension of strategic agility is resource fluidity. Innovating a firm’s product and service portfolio requires a high degree of resource flexibility [32]. The ability to allocate/reallocate resources is thus fundamental to firms’ initiatives toward new developments and offerings [30]. As Doz and Kosonen [10] suggested, business models become less rigid and open to modifications and reinvention with increasing resource fluidity. Given that financial resources, personnel, and other basic competencies are highly mobile within the firm, the firm gains greater flexibility in reorganizing itself or redeploying its resources to support 
its new strategic agenda or to meet evolving market needs that may call for new product/service offerings, new customer/market segmentations, and/or alternative channels to reach customers. As such, resource fluidity plays an important role in facilitating the process whereby the firm reassesses its value propositions for its customers, particularly in resource-constrained firms. Resource fluidity also plays an important role in enabling the firm to decouple or modularize internal and external resources $[10,38]$ and to reconfigure/recombine available resources and integrate them with new resources [33]. Finally, the mobilization, reallocation, and redeployment of various forms of resources causes the firm to revisit its cost-revenue structure since these systemic resource-based changes tend to reflect the shift in the firm's strategic priorities [29]. The above discussion leads us to the following hypotheses:

Hypothesis 1: Strategic agility is positively related to BMI.

H1a: Strategic agility is positively related to value proposition innovation.

H1b: Strategic agility is positively related to value creation innovation.

H1c: Strategic agility is positively related to value capture innovation.

\section{B. The Moderating Effect of Environmental Turbulence}

Beyond understanding the link between strategic agility and BMI adoption, we argue that this relationship is contingent on the environment in which the firm operates. Specifically, we argue that the degree of environmental turbulence further strengthens the relationship between strategic agility and BMI adoption. Environmental turbulence refers to the degree of instability and unpredictability in the industry environment [43]. Environmental turbulence is associated with the magnitude and unpredictability of changes in market trends. Turbulent environments are characterized by rapid changes in customer preferences and technological developments [44, 45]. Firms operating in turbulent environments often face the challenges of continuous innovation and product differentiation from their competitors [43]. Because turbulent environments create ongoing market opportunities and crises [43], firms in such environments operate under constant pressure to not only respond quickly to changing market conditions but also learn to proactively anticipate and adapt their strategies accordingly [45]. In the context of BMI, we expect firmlevel strategic agility to have a stronger influence on BMI adoption particularly in turbulent environments. 
Strategic agility involves firms’ ability to sense changing market conditions and mobilize organizational resources to respond to these changes in a timely manner. In a turbulent environment within which changes in customer preferences, technological developments and competitor behavior are prevalent, strategically agile firms will be in a better position to effectively respond to these changes quickly and to adapt by embracing BMIs. Furthermore, since environmental turbulence increases the demand for more informationprocessing, strategically agile firms operating in such environments will be more effective in leveraging their leadership capability to capitalize on changing market trends. Consequently, it is reasonable to expect that the degree of environmental turbulence further strengthens the relationship between firm-level strategic agility and BMI adoption by creating a sense of urgency and a challenge for firms to further utilize their strategic agility to effectively adapt to their environments through innovative business models. The above discussion leads us to the following hypothesis:

Hypothesis 2: The degree of environmental turbulence positively moderates the relationship between strategic agility and BMI such that strategic agility is more strongly associated with BMI in more turbulent industry environments.

\section{BMI and Firm Performance}

Scholars have acknowledged that the significant role that business models play in firm performance and in generating competitive advantage $[5,28]$. However, to achieve a sustainable competitive advantage, organizations increasingly find it necessary not only to leverage their well-functioning business model but also to constantly update it $[30,46]$. Innovative business models enable firms to commercialize their ideas, resources and products in new strategic, operational and economic ways [28]. Value proposition innovation helps firms to extend their product and service portfolios and address new market needs, which have been instrumental to firm performance [47]. New value creation approaches provide alternative ways to strengthen firm performance since new configurations of activities/key processes and emerging new technologies/capabilities can both enable existing value propositions to produce greater economic results (i.e., more effective exploitation) and complement the new value propositions of firms (i.e., more effective exploration) [48]. Value capture innovation helps firms to realize new revenue streams, in addition to 
existing revenues, or to substitute the less profitable ones [49], thus enhancing the prospect of future returns. Value capture innovation can also strengthen business performance through improved cost structure, resulting in the reduction of inefficiencies [48]. The above discussion leads us to the following hypotheses. Hypothesis 3: BMI is positively related to firm performance.

H3a: Value proposition BMIs are positively related to firm performance.

H3b: Value creation BMIs are positively related to firm performance.

H3c: Value capture BMIs are positively related to firm performance.

\section{D. $\quad$ The Mediating Role of Business Model Innovation (BMI)}

While most of the scholarly work in the business model literature has focused on empirically examining the relationship between BMI and firm performance, relatively less scholarly emphasis has been devoted to understanding BMI as an intermediary strategic mechanism. In this study, we propose that BMI serves as an important intermediary strategic mechanism linking firm-level strategic agility and firm performance. In doing so, we explore how strategically agile firms achieve superior firm performance. Strategic agility has been conceptualized in this paper as the firm's ability to display strategic sensitivity (sensing shifts in environmental trends), develop leadership unity (providing managerial direction that rallies organizational members) and create resource fluidity (organizational ability to marshal resources to exploit market opportunities). Accordingly, strategically agile firms are well positioned to not only regularly detect changes in the marketplace (e.g., shifts in customer preferences, technological developments or competitor actions) but also to respond promptly to these changes.

How does strategic agility enhance firm performance? Several explanations exist in the strategic management literature. Some scholars have argued that strategic agility increases the range and diversity of strategic actions by the firm [50]. For instance, Nadkarni and Narayanan [50] defined strategic flexibility (similar to agility) as "the ability to precipitate intentional changes and adapt to environmental changes through continuous changes in current strategic actions, asset deployment, and investment strategies” (p. 245) and empirically demonstrated its positive effect on firm performance by increasing the speed with 
which firms introduce new products and services to the market. Similarly, other scholars [51] argued that strategic agility enables firms to rapidly respond to market changes by altering "the number of product variations offered, the frequency of new model introductions, as well as the number of entirely new products introduced” (p. 1126). In summary, the strategy literature has suggested that strategic agility enhances firm performance by influencing the range and intensity of strategic actions. In this study, we extend the current discourse by arguing that strategic agility enhances firm performance since it leads to the adoption of BMIs. As we discussed earlier in the paper, the adoption of value creating, value capturing, and value proposition BMIs significantly improves a firm's performance by enabling it to identify and exploit market opportunities associated with the continuously evolving nature of customer value. These three types of BMIs serve as intermediary strategic actions linking strategic agility and firm performance because they allow the firm to translate its "market intelligence"—its ability to detect and analyze market changes—into concrete strategic actions that take advantage of these new market developments. Value creating BMIs help firms to identify important marketplace changes with regard to new technology and new capabilities. Value capture BMIs allow the firm to respond to marketplace changes by instituting novel revenue models and revised cost structures. Finally, value proposition BMIs enable the firm to adapt to marketplace changes by launching new product and services, as well as entering new product markets. These three BMIs collectively create a robust strategic action through which strategically agile firms improve their performance. The above discussion leads us to the following hypothesis:

Hypothesis 4: BMI mediates the relationship between strategic agility and firm performance.

Fig. 1 below presents the research model for our study.

\section{--- Insert Fig. 1 about here ---}

\section{METHODOLOGY}

\section{A. Sample}

The empirical investigation of this study is based on survey data gathered from 432 German firms 
operating in the electronics industry. Using sample firms from one industry, while potentially limiting the broader generalizability of findings, can enhance the internal validity of a study as it reduces potential biases stemming from various industry-specific exogenous factors [52]. The electronics industry was chosen because it is typically characterized by a high level of innovation and competitive intensity, thus serving as appropriate context for the analysis of BMIs. In line with the typical market structure in this industry, our sample covers mostly small to medium-sized companies: $45.8 \%$ with up to 50 employees, $41.1 \%$ with 51 to 500 employees, and $13.2 \%$ with more than 500 employees.

The data for our study were collected in 2014 at international industry-specific trade fairs ${ }^{3}$ of the electronics industry (PCIM Europe, Sensor \& Test, Electronica) held in Germany, using in-person data collection approaches. Trained research assistants attended the trade fairs, collecting survey data based on a questionnaire from respondents. Specifically, the survey was administered by a group of 12 research assistants who participated in a seminar on BMI. All interviewers were knowledgeable about the concepts and were able to answer questions to ensure content validity. Furthermore, the research assistants were trained on the interview procedure prior to data collection. To ensure sampling adequacy, we prescreened the lists of exhibitors and only considered for-profit firms. This process resulted in a list of 1554 potential respondents. We spoke to representatives of these firms and asked about the availability of a person involved in strategic management activities. We asked for an appointment only if such a person was present. To incentivize participation, we offered each firm a written report of our completed study. Before collecting the survey data, we asked each potential respondent about his/her position in the firm, as well as his/her knowledge about the business model, to ensure that he/had had sufficient knowledge about their company. The use of a key informant to obtain firm-level data is considered valid and reliable, particularly in the context of small to medium-sized firms, due to greater information transparency and limited organizational

\footnotetext{
${ }^{3}$ Trade fairs are considered important forums for companies that belong to an industry, thus capturing representative samples of an industry population [53]. The use of trade fairs as the sampling frame also allowed us to directly test the non-response bias as we noted the names of those companies that declined to participate. We collected information about their company size and product range and compared these to our sample firms. The results indicated no significant differences between them, suggesting that non-response bias was not a significant concern.
} 
complexity [54]. We strengthened the validity of the key informant approach by ensuring that prospective respondents held relevant managerial positions in their firms. Since we collected our data at international trade fairs, our sample captures responses from a variety of different countries, including the following: 58.6\% from Germany, 22.9\% from other EU countries (incl. the UK and Switzerland), 10.0\% from the BRIC countries, 6.9\% from North America (the USA and Canada), and 1.6\% from Asia (e.g., Japan). With regard to respondents' managerial positions, $31.2 \%$ of them were CEOs, $35.0 \%$ were geographic managers, and 33.8\% held functional management positions (e.g., innovation management, business development). The overall response rate of this survey was $27.8 \%$. Since we collected independent and dependent variables from the same respondents, there was a risk of common method bias (CMB) in our data. To prevent potential confounding effects, we systematically accounted for CMB using ex ante and ex post approaches [55]. We guaranteed respondent anonymity and designed the survey in such a way that specific measurement items were not adjacent to each other. We also used second-order measurement models for the dimensions of BMI, consisting of several subconstructs that were not obviously linked to each other, to reduce the potential impact of $\mathrm{CMB}$ on the intended causal structure. As an ex post approach to assess CMB, we applied the correlational marker technique [56]. We measured the respondents' degree of illusion of control as a marker variable that was theoretically unrelated to our constructs. In line with Langer [57], we asked respondents about their propensity, ranging from 1 to 5 on a semantic differential scale, to either rely on a consultant's opinion or decide independently when making a stock market investment. We controlled for this marker variable in a partial correlation analysis of the model constructs. Since all zero-order correlations remained significant after inclusion of the marker variable, we found no indication of CMB.

\section{B. $\quad$ Measurement Instrument}

We operationalized our model based on measurement scales established in previous studies. Table II depicts the scale items used in this study ${ }^{4}$. To measure strategic agility, we adapted items from Hock et al.

\footnotetext{
${ }^{4}$ We measured each item on a five-point Likert-type scale ranging from 1: strongly disagree to 5: strongly agree. As some measures had to be adapted to the context of our study, we went through a two-step pretest process to ensure the validity of our survey. First, we presented the initial survey to 21 students in a master's course in BMI. These graduate students had broad
} 
[12], who provided validated items based on the dimensions of Doz and Kosonen [10]. We aggregated these dimensions (i.e., strategic sensitivity, leadership unity and resource fluidity) into a second-order measure. We operationalized BMI in line with Clauss [17], who developed a comprehensive second-order measurement scale for each of the three dimensions of BMI. We measure firm performance relative to that of direct competitors based on a scale from Venkatraman and Ramanujam [58]. We integrate several control variables into our model to reduce potential confounding effects through omitted variables. Since BMI may be influenced by external and internal conditions of the incumbent [e.g., 49], we accounted for some influencing factors. First, we considered environmental turbulence since firms that face greater turbulence have a greater need to change their business model [48]. To operationalize this variable, we rely on the market turbulence scale of Jaworski and Kohli [59]. Second, the industry with which a firm is involved can exert pressure as well as present opportunities for BMI. To account for this potential influence, we further asked respondents to which industry their firm primarily supplied their output (automotive, construction, engineering, etc.). Third, firm size can also play a role in influencing BMI. On the one hand, small firms are more flexible in decision making and resource reallocation. On the other hand, small firms usually lack relevant financial resources, must be careful in risk taking and have limited access to market and technological information. We measured firm size with the logarithm of the number of employees.

\section{Specification and Estimation of the Model}

We specified the conceptual framework as a structural equation model using the partial least squares (PLS) approach [60]. PLS has attracted attention recently in management research [61] and has certain advantages for this study, compared to covariance-based structural equation modeling. PLS is more appropriate when it is necessary to use latent variable scores in subsequent analyses [62], as is the case in our analysis. PLS enables the use of formative and reflective indicators [63] and is particularly appropriate

professional expertise and had received theoretical training on the topic. They commented on their understanding of the items in the initial instrument and verified the clarity of the wording. Thus, we were able to assess and improve the understandability and readability of the survey. In a second step, we sent the survey to randomly selected managers from firms in the electronics or engineering industry. After receiving 30 completed surveys, we analyzed the distributions and reliabilities of the scales and reworded some items to adjust the scales before finalizing them for the full-scale survey. 
for $2^{\text {nd }}$-order measurement models [64]. We obtained the standard errors for the estimates of the measurement and structural model by nonparametric bootstrapping with 5,000 replications with individual sign changes and case-wise deletion of missing values [62]. While the constructs of strategic agility and performance are first-order reflective measures, value creation innovation, value capture innovation and value proposition innovation are specified as second-order constructs. Since we specified the higher-order constructs as type II reflective-formative models [64], we apply the two-step approach (i.e., sequential latent variable score method) for estimation $[64,65]$. This approach should be used whenever the structural equation model involves a formative hierarchical latent variable model in an endogenous position, and the main interest lies in the effects between the higher-level constructs [66]. The estimation then requires two sequential steps. First, we calculated factor scores of the first-order constructs in a model, without the presence of second-order constructs. Second, we used these factor scores as formative indicators of the second-order hierarchical latent variable in a separate second-stage analysis $[65,66]$.

\section{RESULTS}

\section{A. Measurement Model Evaluation}

Testing the distributional assumptions of our indicators, univariate normal distribution (i.e., skewness and kurtosis measures $<|1|)$ was found for 50 of 51 variables. Only one variable showed kurtosis of -1.3 , which was slightly greater than the threshold. Reflective first-order constructs were assessed based on common reliability and validity measures [62]. All indicator loadings exceeded the threshold value of 0.7 [63], providing good indicator reliability. The composite reliability of all reflective constructs was higher than 0.7 , substantiating internal consistency [62]. Convergent validity was substantiated since all constructs exceeded an average variance explained (AVE) of 0.5 [67]. Since all AVE values exceeded the highest squared interconstruct correlations, discriminant validity according to the Fornell-Larcker criterion was confirmed. We further tested the hetrotrait-monotrait (HTMT) ratio criteria and the HTMT inference criteria for all first-order constructs. All HTMT values were significantly less than the conservative threshold of 
0.85 [68], and the HTMT inference criterion indicated that all of the HTMT values are significantly different from one [69]. Table II shows the results of the assessment of the reflective outer measurement model.

\section{--- Insert TABLES I and II about here ---}

We further assessed the second-order formative constructs (Table III). Traditional tests for indicator reliability and convergence are obsolete for formative measures as there are no ex ante assumptions about the strength of the relationship of individual indicators and the construct [62]. Since a formative measurement is based on multiple regressions, multicollinearity should be tested. We calculated the variance inflation factors (VIF) for each first-order construct used for formative measurement of value creation innovation, value capture innovation and value proposition innovation. All of the values were far less than the common threshold value of 10 (VIF $<2)$; thus, multicollinearity is not an issue in our model [62]. The relative importance of each formative indicator was assessed based on the second-order weights [66]. All except two first-order constructs significantly form their second-order constructs. As formative indicators with insignificant weights are still conceptually related to their constructs, they should be kept in the model [62].

\section{--- Insert TABLE III about here ---}

\section{B. Hypothesis Testing}

To test the effects of the control variables, we first calculated a model that only included our control variables and their effects on the endogenous constructs. Although this model showed some significant effects, the controls accounted for a relatively small variance of the endogenous constructs with $\mathrm{R}^{2}$ less than 0.05. After including our hypothesized variables in the model (Model 2), the $\mathrm{R}^{2}$ values of all endogenous constructs significantly improved compared to those of the control model. Hypothesis 1 proposed a positive relationship between strategic agility and the three types of BMI. As seen from Model 2, strategic agility is associated with higher value proposition innovation $(\beta=0.573, \mathrm{p}<0.001)$, higher value creation innovation $(\beta=0.604, \mathrm{p}<0.001)$ and higher value capture innovation $(\beta=0.359, \mathrm{p}<0.001)$. Hypothesis 2 proposed that the degree of environmental turbulence positively moderates the relationship between strategic agility and 
the three types of BMI. To test this hypothesis, we included the interaction effects of strategic agility and environmental turbulence in Model 3 in Table IV for value proposition, value creation and value capture. This model also shows good model fit but no substantial improvement compared to the main effects (Model 2). We find a positive moderating effect of environmental turbulence on the effect between strategic agility and each dimension of BMI (value proposition innovation: $\beta_{\text {int }}=0.083, p<0.05$, value creation innovation: $\beta_{\text {int }}=0.060, \mathrm{p}<0.1$, value capture innovation: $\left.\beta_{\text {int }}=0.106, \mathrm{p}<0.05\right)$. Overall, these significant coefficients provide empirical support for Hypothesis 2. In other words, the higher that the environmental turbulence is, the stronger the effect of strategic agility is on BMI. To gain a deeper understanding of the effect of strategic agility under different degrees of environmental turbulence, we plotted the marginal effects [70] of strategic agility on each dimension of BMI along various degrees of environmental turbulence (see Fig. 2 below). We additionally show the $95 \%$ confidence interval. The marginal effect is significant when the upper and lower bounds of the confidence interval are both either above or below the zero line. We see that the positive marginal effect of strategic agility on BMI increases with a higher degree of environmental turbulence.

\section{--- Insert Fig. 2 about here ---}

Hypothesis 3 proposes that each of the three types of BMIs are positively related to firm performance. The results in Model 2 of Table IV provide mixed support for this hypothesis. The significant effect between value proposition innovation and performance $(\beta=0.142, p<0.10)$ provides some support to Hypothesis 3a. Value creation innovation has a positive and significant relationship with firm performance ( $\beta=0.213, \mathrm{p}<0.01$ ), supporting Hypothesis 3b. Contrary to our prediction, we found a negative effect between value capture innovation and firm performance $(\beta=-0.121, \mathrm{p}<0.05)$. Thus, Hypothesis $3 c$ was not supported. Our main effect model (Model 2) showed a good overall model fit according to the standardized root mean square residual (SRMR) since the value of 0.077 is less than the conservative cut-off of 0.080 [71]. Overall, the model explains reasonably high degrees of variance: $35.8 \%$ for value proposition innovation, 40.5\% for value creation innovation, and 20.9\% for value capture innovation. Furthermore, the three dimensions of BMI collectively explain 32.0\% of the firm performance. As firm performance depends 
primarily on the efficiency and effectiveness of day-to-day operations, this degree of variance explanation emphasizes the importance of regular business model adaptations to remain competitive. We evaluated the predictive relevance of the model by testing Stone-Geisser's $Q^{2}$ values [60] for all endogenous constructs. All values are greater than zero and thereby indicate the model's adequate predictive validity. Table IV provides an overview of the path estimates and the model fit.

\section{--- Insert TABLE IV about here ---}

Finally, Hypothesis 4 proposed that BMI significantly mediates the relationship between strategic agility and firm performance. Model V below presents the results of the mediation test. We analyzed the indirect effects in our model to assess whether the effect of strategic agility on firm performance is mediated through BMI [72]. We find that the total indirect effect of strategic agility via BMI on performance is positive and significant $\left(\beta_{\text {ind }}=0.166, \mathrm{p}<0.001\right.$ ), indicating a mediating effect. This overall effect is the result of a positive and significant indirect effect of strategic agility on firm performance via value creation innovation $\left(\beta_{\text {ind }}=0.128, \mathrm{p}<0.01\right)$ as well as via value proposition innovation $\left(\beta_{\text {ind }}=0.081, \mathrm{p}<0.05\right.$.

\section{--- Insert TABLE V about here ---}

To assess the scope of this mediation effect, we further compared the direct effects of strategic agility on performance in our test of Model 2 in Table IV above to a model that only calculates the direct effect of strategic agility on firm performance without the presence of mediators [73]. In this model, strategic agility yields a significant, direct effect on firm performance $(\beta=0.495, \mathrm{p}<0.001)$. This effect drops after the mediator is included but remains significant $(\beta=0.329, \mathrm{p}<0.001)$. Hence, we found partial mediation of the effect of strategic agility on firm performance through BMI, supporting our hypothesis 4 .

\section{Follow-up Test with Secondary Performance Data}

Since the survey-based findings regarding the link between value capture innovation and firm performance seem counterintuitive, we decided to conduct a follow-up test with available secondary data 
to cross-validate the relationships between BMI dimensions and firm performance ${ }^{5}$. The results of this follow-up test substantiated two of our findings from the survey data, as follows: (1) the negative effect of value capture innovation on firm performance $(\beta=-0.422, \mathrm{p}<0.05)$; and $(2)$ the positive effect of value proposition innovation on firm performance $(\beta=0.259, \mathrm{p}<0.1)$, thus providing converging evidence. However, value creation innovation had no significant effect on firm performance in the follow-up test with secondary data, thus diverging from the findings from the survey data.

\section{POST HOC SEMI-STRUCTURED INTERVIEWS}

The negative effect of value capture innovation on firm performance, which was consistently significant in both empirical tests, indeed counters our hypothesized relationship and its underlying theoretical arguments. To explore the potential mechanisms underlying this significant and negative effect further, we conducted semistructured interviews with eleven managers involved with their firms’ value capture innovation efforts. The interview questions focused specifically on their firms' events related to the implementation of value capture innovation and the subsequent outcomes. The relatively narrow field of interview questions help to increase the likelihood that data saturation would be reached with a reasonable number of interviews [76]. Since no new insights were forthcoming from the interviews, data saturation was reached, and the interviews were concluded after eleven interviews. The interviews were then transcribed into interview notes, enabling us to recursively analyze the data and repeat the data-interrogating

\footnotetext{
${ }^{5}$ In doing so, we gathered all available company data regarding firm performance from company databases (e.g. wiso-net.de: leading database for German language corporate information; corporateinformation.com: international database for corporate information) and from the companies’ websites if no information was found in the databases. Because of many small to mediumsized companies in our sample, the majority of the firms are not obligated to publish their financial statements, and reliable financial performance data are not always available. Hence, we retrieved secondary performance data for 72 (16.7\%) of the firms in our sample. We compared the remaining firms with these 72 firms regarding their characteristics (i.e., firm size and industry focus as well as all first order reflective constructs) by running several $\mathrm{Chi}^{2}$ and t-tests and found no significant differences between them, thus mitigating a concern about systematic biases underlining the available secondary data for the robustness check purposes. In this robustness testing, we used earnings before interest taxes, depreciation and amortization (EBITDA) as a proxy for firm performance, which is a frequently used performance measure in firm profitability studies [74, 75]. Due to some missing values in the relevant values, we could calculate this value for 62 out of the 72 firms. We then used the factor scores of our second-order measures of the BMI dimensions from the previous estimations. We dropped the industry control dummy because of the limited variance in the industry focus of the sample for this robustness check. The full results of this robustness check can also be made available upon request from the corresponding author.
} 
process, enhancing the reliability and validity of the eventual findings [77]. The data analysis was conducted by two researchers. To ensure the reliability of the results, their identified mechanisms were compared and discussed to draw conclusions about their meaning. More details on the interview procedure and the summary of key findings can be, respectively, found in Appendices A and B.

Two key insights emerged from the interviews (see Appendix B). First, value capture innovation is a systemic change that can disrupt the system and, thus, requires mutual adjustment efforts from other parts in the system. Otherwise, value capture innovation may lead to local optimization and overall performance being compromised. Second, the local optimization problems can occur in three domains: functions, people, and partners. When the value capture model changes, it requires various functional activities in the firm to adjust and realign with the new value capture model. The licensing-to-subscription model shift of software companies and the revenue model change from selling to a renting-selling mix of an automotive company in the interviews illustrated the need for changes in functional activities, such as sales agreements/contracts, accounting, billing processes, marketing, etc., to fit with the new value capture model. Unless the mutual adjustments of related functional activities are made in a timely manner, the local optimization problem would ensue. The local optimization problem can occur due to a lack of readiness or relevant knowledge from the people involved since the new value capture model may require different knowledge/skill sets and/or new mindsets. The change from “...selling availability instead of machines” by a logistic service provider company and the shift from the product-based to the service-based revenue model of a diversified electronics company in the interviews created challenges for their employees from higher up to the frontline calls for their rethinking. Finally, the local optimization problem can stem from the resistance of partners in the business ecosystem, interest in which may either be potentially undermined or possibly become less certain with the new value capture model. The revenue model change from selling to renting of a tool-maker company in our interviews led to the poor results of the company as inherent conflicts of interest and obstacles from their partners were raised. 


\section{DISCUSSION AND CONCLUSION}

The aim of this study is to establish and test the missing link between strategic agility and BMI. Our empirical findings indicate that strategic agility (which is comprises strategic sensitivity, leadership unity, and resource fluidity) is positively associated with three dimensions of BMI: value proposition, value creation and value capture innovations. Furthermore, the results of our empirical analyses provide strong support for our argument that the degree of environmental turbulence strengthens the relationship between strategic agility and BMI adoption. This finding highlights the importance of industry context and suggests that strategically agile firms are more inclined to adopt BMIs when they operate in turbulent environments.

We further examine the relationships between these three dimensions of BMI and firm performance. Our results provide mixed support regarding the hypothesized performance effects of value proposition, value creation and value capture innovation. Our findings show that, while value proposition and value creation have positive relationships with firm performance, value capture innovation was in fact negatively related to firm performance. The hypothesized positive relationship between value creation innovation and firm performance is supported. A possible explanation for this discrepancy is that value creation innovation may give the firm a competitive advantage over its direct competitor since it helps the firm to achieve greater business performance in multiple related dimensions (e.g., market share, sales growth, organizational development, etc.). These business improvements, however, may not readily translate into financial results from the accounting standpoint. Additionally, the attempts to change or innovate the process of value creation may even result in temporary operational disruptions or greater administrative intensity [78], the costs of which can offset the potential financial gains from this value creation innovation in the near term. Value proposition innovations that can rest upon the existing value creation processes may not suffer from this near-term setback since the new value propositions can be delivered through the current processes without much interruption. Thus, the link between value proposition innovation and firm performance was supported by both empirical tests, using the perceptual performance measure relative to direct competitors, as well as the absolute accounting-based performance measure. With regard to the negative effect of value 
capture innovation on firm performance, this finding is not in line with studies that explicitly highlighted the benefits related to new revenue models $[4,46,49]$. The exploratory interview results suggest that value capture innovation is a systemic change in nature, thus requiring other parts in the business system to make mutual adjustments to have them optimally fit with the new value capture model. Otherwise, the implementation of such a new model can only become a local optimization effort [79, 80], whereby gains in one area can impose costs/expenses on other areas or even to the whole system. From the system perspective [29, 31], the isolated attempt toward value capture innovation could be counterproductive unless such an attempt is accompanied by adequate and timely mutual adjustments to other parts of the system. The interviews indicate that the mutual adjustment efforts necessary to render a new value capture model successful are in the domains of related functional activities, people, and partners involved in the business ecosystem. If not, firm performance may suffer from local optimization issues. Finally, the results of our mediation tests indicate that BMI serves as an important intermediary mechanism through which firms’ strategic agility contributes to superior firm performance. We believe that the inclusion of this process further extends our understanding of the role of BMIs as important strategic conduits, thus showing how strategic mindsets (such as agility) influence firm performance beyond the exploration of their direct effects.

\section{A. Contributions to Research}

Our study contributes to the emerging literature stream on BMI management [13, 14] and the organizational drivers of BMI in general $[46,81]$ in several ways. First, we provide systematically and empirically validated insights into enablers of BMI. Based on dynamic capability theory and with a specific focus on capabilities for strategic agility, we identify strategic sensitivity, leadership unity, and resource fluidity as enablers of BMI. The inclusion of these enablers in the BMI literature helps to shape the understanding of BMI as a systematic and structured process rather than as the result of trial and error [82]. Second, we provide theoretical reasoning and empirical evidence for considering BMI as a reconfiguration of different business model dimensions [19, 26, 27]. Although business models are often referred to as being activity systems composed of interdependent elements and activities [31], research so far has mainly 
focused on the effects of certain enablers on: (a) one of these dimensions (e.g., value creation) [30]; (b) BMIs as aggregated constructs [83]; or (c) proxy measures, such as the propensity to change the business model [12]. In this study, we distinguish the three dimensions of value proposition innovation, value creation innovation and value capture innovation in one empirical model. We determined the following: (a) different capability enablers affect each dimension of BMI differently; (b) the three BMI dimensions have different performance consequences; and (c) value capture innovation requires mutual adjustments of other parts in the business ecosystem; otherwise, there is a danger of local optimization. As such, these collective findings suggest that aggregating BMI into one holistic concept might suppress our nuanced understanding of the underlying mechanisms. Third, we extend the predominant understanding of the link between strategic agility and firm performance by highlighting the mediating role of BMI. Our findings generally support the positive effect of strategic agility on firm performance [84] but also show that BMI is an important mediator in this relationship. Hence, we advance previous knowledge by showing that the existence of strategic agility per se might not optimally improve firm performance unless it is channeled through BMI, which can, in turn, influence firm performance. In addition, our moderation test shows relatively consistent positive effects of strategic agility on BMI, which in turn influence firm performance, despite varying degrees of environmental turbulence. As strategic agility is conceptually built on dynamic capabilities, this new robust finding may indirectly shed a new light on the strategic flexibility and dynamic capability literature as well. The dynamic capability literature has predominantly been advanced on the contingency notion that various forms of dynamic capabilities significantly endow firms with competitive advantage during times of environmental changes [36, 50, 84]. Logically extending from the findings of our robustness tests, one may inquire whether dynamic capabilities, if leveraged toward BMI, could also be fundamental to firms' competitive advantage, independent of environmental changes. This inquiry will potentially motivate future research to question and perhaps expand the boundary condition of dynamic capability theory beyond the current predominant contingency view. Future research is needed in advancing the literature in this direction. Finally, we note that the impact of particular business model dimensions on 
overall firm performance is not homogenous and might even be negative for value capture innovation. Thereby, we challenge a recent research direction that has focused largely on positive effects of BMI on firm performance [e.g., 46]. Our findings in this study add to the competitive advantage literature by providing a more nuanced understanding of the performance outcomes of BMIs.

\section{B. Managerial Implications}

Managers can draw three useful implications from our study. First, managers who want to successfully implement BMIs should attempt to develop their firms’ capabilities toward strategic agility (i.e., strategic sensitivity, leadership unity, and resource fluidity) to lay important foundations for subsequent BMIs. Second, managers should be aware that different dimensions of BMIs are influenced by different enablers to various degrees. Capabilities with high impacts on value creation innovation differ from those with high impacts on value capture innovation. Matching a specific capability with a specific dimension of BMI to which the firm is striving will help to render its efforts more productive. Finally, managers would benefit from knowing that the three dimensions of BMI have different performance outcomes. Despite the potential positive effects of BMI, our findings indicate inconsistent results for the positive performance effects of value creation innovation, as well as the consistent, negative performance effects of value capture innovation. Through a posteriori reasoning, we explain such findings through the lenses of system and strategic perspectives [6, 29, 31]. In light of these findings and the logical reasoning underlying them, managers should also realize that their efforts toward value creation and value capture innovation could potentially be wasteful or even counterproductive if such efforts are localized instead of being integrative and are not implemented within the strategic context of the firm.

\section{Limitations and Outlook for Future Research}

Our study has a few limitations that could stimulate future research. First, it is important to mention the sector-specific data selection in this study with our sample firms being from the electronics industry. As this industry lies in the high-technological sector, one might expect higher innovation rates than in other 
industries (e.g., the service sector). Hence, further research should test the generalizability of our findings in other industries. Similarly, we recognize that the use of data collected in 2014, while insightful, may not be up to date given the dynamic nature of the electronics industry. Second, our study did not account for the effect of firm age on the development of BMI. As the entrepreneurship literature attests, younger firms are more likely to pursue BMI than their older counterparts across various industry sectors. Accordingly, future studies should consider the dynamics of firm age in their research models. Third, contrary to our predictions and prior work in the literature, we found that value capture innovation was in fact negatively related to firm performance. Our results from the semistructured interviews helped to further explore this phenomenon and to reveal that local optimization could be an issue that explains the negative consequences of value capture innovation. However, this outcome might not yet provide a comprehensive explanation for this phenomenon. Accordingly, we encourage future research to further investigate this phenomenon, in which value capture innovations may not necessarily improve firm performance. One possibility would be to further explore the initial findings of local optimization issues based on the analysis of the performance of different business model system configurations, for example, via fuzzy-set analyses. Another possibility could be that the adoption of such a business model system may benefit the firm in the long term by improving its competitiveness despite its limited effectiveness to boost short term performance. In our study, we were not able to use a longitudinal data collection approach. Such an approach would have enabled us to measure the adoption of value capture innovations first, followed by firm performance at a later time. We encourage researchers to utilize a longitudinal research design in investigating this issue. Fourth, the negative main effect of value capture innovation on firm performance may indicate an interesting research direction of the system perspective [29, 31] on the dimensions of BMI. The main effects of individual dimensions (i.e., parts) are incomplete outside the context of the system in which they interact and shape the performance of the whole system. As the positive performance effect of value proposition innovation is found to be consistent and as hypothesized, we speculate that value proposition innovation may be the primacy dimension of the system that sets the pace and pattern for the other two dimensions 
(i.e., value creation and value capture innovations) to operate. Finally, despite our efforts to provide a valid and robust empirical analysis, this analysis can only be the first step into large-scale empirical research in this domain. Causal conclusions in our study can only be drawn through theoretical reasoning as we could not formally control for endogeneity and empirically establish causality. It is possible that firm-level strategic agility can also be a consequence of BMI. As Schneider and Spieth [85] demonstrated in their scenario-based experiment, the occurrence of BMI adoption could provoke the perception among observers that the firms are flexible or agile if considered in the context of this study. However, whether firms indeed become more flexible or more agile as a result of BMI could not be addressed through the scenario-based experiment in their study or through the cross-sectional survey in this study. A longitudinal research design is needed to address this inquiry. If strategic agility is empirically demonstrated as both an antecedent/enabler and a consequence/outcome of BMI, then the relationship between strategic agility and BMI will be dynamic in nature, which will be an important finding in advancing our understanding of strategic agility and BMI. This line of research could prove very fruitful in the future. 


\section{References}

[1] N. J. Foss and T. Saebi, "Fifteen Years of Research on Business Model Innovation," Journal of Management, vol. 43, pp. 200-227, 2017/01/01 2016.

[2] G. Pohle and M. Chapman, "IBM's global CEO report 2006: business model innovation matters," Strategy \& Leadership, vol. 34, pp. 34-40, 2006.

[3] R. Amit and C. Zott, "Creating value through business model innovation," MIT Sloan Management Review, vol. 53, pp. 41-49, Spr 2012.

[4] R. Casadesus-Masanell and F. Zhu, "Business model innovation and competitive imitation: The case of sponsor-based business models," Strategic management journal, vol. 34, pp. 464-482, 2013.

[5] C. Zott, R. Amit, and L. Massa, "The Business Model: Recent Developments and Future Research," Journal of Management, vol. 37, pp. 1019-1042, July 1, 20112011.

[6] C. Zott and R. Amit, "The fit between product market strategy and business model: implications for firm performance," Strategic Management Journal, vol. 29, pp. 1-26, 2008.

[7] J. Aspara, J. Hietanen, and H. Tikkanen, "Business model innovation vs replication: financial performance implications of strategic emphases," Journal of Strategic Marketing, vol. 18, pp. 39-56, 2010.

[8] D. J. Teece, "Explicating Dynamic Capabilities: The Nature and Microfoundations of (Sustainable) Enterprise Performance," Strategic Management Journal, vol. 28, pp. 1319-1350, 2007.

[9] D. J. Teece, G. Pisano, and A. Shuen, "Dynamic capabilities and strategic management," Strategic Management Journal, vol. 18, pp. 509-533, 1997.

[10] Y. L. Doz and M. Kosonen, "Embedding Strategic Agility: A Leadership Agenda for Accelerating Business Model Renewal," Long Range Planning, vol. 43, pp. 370-382, 2010.

[11] Y. Weber and S. Y. Tarba, "Strategic agility: A state of the art," California management review, vol. 56, pp. 5-12, 2014.

[12] M. Hock, T. Clauss, and E. Schulz, "The impact of organizational culture on a firm's capability to innovate the business model," R\&D Management, vol. 46, pp. 433-450, 2016.

[13] E. Bucherer, U. Eisert, and O. Gassmann, "Towards Systematic Business Model Innovation: Lessons from Product Innovation Management," Creativity and Innovation Management, vol. 21, pp. 183198, Jun 2012.

[14] P. Lindgren, "Business Model Innovation Leadership: How Do SME’s Strategically Lead Business Model Innovation?," International Journal of Business and Management, vol. 7, pp. 53-66, 2012.

[15] C. M. DaSilva and P. Trkman, "Business Model: What It Is and What It Is Not," Long Range Planning, vol. 47, pp. 379-389, 2013.

[16] P. Spieth, D. Schneckenberg, and J. E. Ricart, "Business model innovation - state of the art and future challenges for the field," R\&D Management, vol. 44, pp. 237-247, 2014.

[17] T. Clauss, "Measuring Business Model Innovation: Conceptualization, Scale Development and Proof of Performance," R\&D Management, vol. 47, pp. 385-403, 2017.

[18] P. Spieth and S. Schneider, "Business model innovativeness: designing a formative measure for business model innovation," Journal of Business Economics, vol. 86, pp. 671-696, 2016// 2016.

[19] L. Massa and C. L. Tucci, "Business Model Innovation," in The Oxford Handbook of Innovation Management, M. Dodgson, D. Gann, and N. Phillips, Eds., ed Oxford: Oxford University Press, 2014, pp. 420-441.

[20] M. Morris, M. Schindehutte, and J. Allen, "The entrepreneur's business model: toward a unified perspective," Journal of Business Research, vol. 58, pp. 726-735, 2005.

[21] D. J. Teece, "Business models, business strategy and innovation," Long Range Planning, vol. 43, pp. 172-194, 2010.

[22] T. Clauss, T. Kesting, and J. Naskrent, "A rolling stone gathers no moss: The effect of customers' perceived business model innovativeness on customer value co-creation behavior and customer satisfaction in the service sector," $R$ \& D Management, 2018. 
[23] A. Osterwalder and Y. Pigneur, Business Model Generation: A Handbook for Visionaries, Game Changers, and Challengers. Hoboken, NJ: Wiley \& Sons, 2010.

[24] C. Baden-Fuller and S. Haefliger, "Business models and technological innovation," Long Range Planning, vol. 46, pp. 419-426, 2013.

[25] M. W. Johnson, C. M. Christensen, and H. Kagermann, "Reinventing Your Business Model," Harvard Business Review, vol. 86, pp. 57-68, Dec 2008.

[26] P. Aversa, S. Furnari, and S. Haefliger, "Business model configurations and performance: A qualitative comparative analysis in Formula One racing, 2005-2013," Industrial and Corporate Change, vol. 24, pp. 655-676, 2015.

[27] T. Clauss, R. Bouncken, S. M. Laudien, and S. Kraus, "Business Model Reconfiguration and Innovation in SMEs: A Mixed-Methods Analysis from the Electronics Industry," International Journal of Innovation Management, in press.

[28] H. Chesbrough, "Business Model Innovation: Opportunities and Barriers," Long Range Planning, vol. 43, pp. 354-363, Apr-Jun 2010.

[29] R. Casadesus-Masanell and J. E. Ricart, "From strategy to business models and onto tactics," Long Range Planning, vol. 43, pp. 195-215, 2010.

[30] L. Achtenhagen, L. Melin, and L. Naldi, "Dynamics of business models - Strategizing, critical capabilities and activities for sustained value creation," Long Range Planning, vol. 46, pp. 1-25, 2013.

[31] C. Zott and R. Amit, "Business model design: an activity system perspective," Long Range Planning, vol. 43, pp. 216-226, 2010.

[32] A. J. Bock, T. Opsahl, G. George, and D. M. Gann, "The effects of culture and structure on strategic flexibility during business model innovation," Journal of Management Studies, vol. 49, pp. 279-305, 2012.

[33] F. Mezger, "Toward a capability-based conceptualization of business model innovation: insights from an explorative study," R\&D Management, vol. 44, pp. 429-449, 2014.

[34] S. Leih, G. Linden, and D. J. Teece, "Business Model Innovation and Organizational Design: A Dynamic Capabilities Perspective," in Business Model Innovation: The Organizational Dimension, N. J. Foss and T. Saebi, Eds., ed New York: Oxford University Press, 2015, pp. 24-42.

[35] H. Makkonen, M. Pohjola, R. Olkkonen, and A. Koponen, "Dynamic capabilities and firm performance in a financial crisis," Journal of Business Research, vol. 67, pp. 2707-2719, 2013.

[36] D. Teece, M. Peteraf, and S. Leih, "Dynamic capabilities and organizational agility: Risk, uncertainty, and strategy in the innovation economy," California Management Review, vol. 58, pp. 13-35, 2016.

[37] A. B. Sambamurthy and V. Grover, "Shaping Agility through Digital Options: Reconceptualizing the Role of Information Technology in Contemporary Firms," MIS Quarterly, vol. 27, pp. 237-263, 2003.

[38] Y. L. Doz and M. Kosonen, Fast Strategy: How Strategic Agility Will Help You Stay Ahead of the Game. London, UK: Wharton School Publishing, 2008.

[39] J. L. Brown and N. M. Agnew, "Corporate Agility," Business Horizons, vol. 25, pp. 29-33, 1982.

[40] C. W. Holsapple and X. Li, "Title," unpublished|.

[41] R. E. Giachetti, L. D. Martinez, O. A. Sáenz, and C.-S. Chen, "Analysis of the structural measures of flexibility and agility using a measurement theoretical framework," International Journal of Production Economics, pp. 47-62, 2003.

[42] M. W. Lewis, C. Andriopoulos, and W. K. Smith, "Paradoxical leadership to enable strategic agility," California Management Review, vol. 56, pp. 58-77, 2014.

[43] J. Haleblian and S. Finkelstein, "Top management team size, CEO dominance, and firm performance: The moderating roles of environmental turbulence and discretion," Academy of Management journal, vol. 36, pp. 844-863, 1993.

[44] S. L. Brown and K. M. Eisenhardt, "The Art of Continuous Change: Linking Complexity Theory and Time-Paced Evolution in Relentlessly Shifting Organizations," pp. 1-34, 1997. 
[45] W. K. Chong, D. Bian, and N. Zhang, "E-marketing services and e-marketing performance: the roles of innovation, knowledge complexity and environmental turbulence in influencing the relationship," Journal of Marketing Management, vol. 32, pp. 149-178, 2016.

[46] J. Karimi and Z. Walter, "Corporate Entrepreneurship, Disruptive Business Model Innovation Adoption, and Its Performance: The Case of the Newspaper Industry," Long Range Planning, vol. 49, pp. 342-360, 6// 2016.

[47] J. K. Han, N. Kim, and R. K. Srivastava, "Market orientation and organizational performance: is innovation a missing link?," The Journal of marketing, vol. 62, pp. 30-45, 1998.

[48] C. Heij, H. Volberda, and F. Van den Bosch, "How does business model innovation influence firm performance: the effect of environmental dynamism," Academy of Management Proceedings, vol. 2014, p. 16500, 2014.

[49] C. Zott and R. Amit, "Business Model Innovation: Creating Value In Times Of Change," Universia Business Review, pp. 108-121, 2009.

[50] S. Nadkarni and V. K. Narayanan, "Strategic schemas, strategic flexibility, and firm performance: The moderating role of industry clockspeed," Strategic management journal, vol. 28, pp. 243-270, 2007.

[51] N. Worren, K. Moore, and P. Cardona, "Modularity, strategic flexibility, and firm performance: a study of the home appliance industry," Strategic management journal, vol. 23, pp. 1123-1140, 2002.

[52] K. R. Harrigan, "Research methodologies for contingency approaches to business strategy," Academy of Management Review, vol. 8, pp. 398-405, 1983.

[53] F. Rolf Seringhaus and P. J. Rosson, "Management and performance of international trade fair exhibitors: government stands vs independent stands," International Marketing Review, vol. 15, pp. 398-412, 1998.

[54] C. Homburg, M. Klarmann, M. Reimann, and O. Schilke, "What drives key informant accuracy?," Journal of Marketing Research, vol. 49, pp. 594-608, 2012.

[55] P. M. Podsakoff, S. B. MacKenzie, J. Y. Lee, and N. P. Podsakoff, "Common method biases in behaviroal research. A critical review of the literature and recommended remedies," Journal of Applied Psychology, vol. 88, pp. 879-903, 2003.

[56] M. K. Lindell and D. J. Whitney, "Accounting for common method variance in cross-sectional research designs," Journal of applied psychology, vol. 86, pp. 114-121, 2001.

[57] E. J. Langer, "The illusion of control," Journal of personality and social psychology, vol. 32, p. 311, 1975.

[58] N. Venkatraman and V. Ramanujam, "Measurement of business performance in strategy research: a comparison of approaches," Academy of management review, vol. 11, pp. 801-814, 1986.

[59] B. J. Jaworski and A. K. Kohli, "Market orientation: antecedents and consequences," The Journal of marketing, vol. 57, pp. 53-70, 1993.

[60] W. W. Chin, "The partial least squares approach to structural equation modeling," in Modern methods for business research, G. A. Marcoulides, Ed., ed Mahwah: Lawrence Erlbaum Associates, 1998, pp. 295-336.

[61] J. F. Hair, M. Sarstedt, T. M. Pieper, and C. M. Ringle, "The use of partial least squares structural equation modeling in strategic management research: A review of past practices and recommendations for future applications," Long Range Planning, vol. 45, pp. 320-340, 2012.

[62] J. F. Hair, C. M. Ringle, and M. Sarstedt, "PLS-SEM: Indeed a silver bullet," The Journal of Marketing Theory and Practice, vol. 19, pp. 139-152, 2011.

[63] W. W. Chin, "How to write up and report PLS analysis," in Handbookof partial least squares: Concepts, methods and applications, V. Esposito Vinzi, W. W. Chin, J. Henseler, and H. Wang, Eds., ed Heidelberg: Springer, 2010, pp. 655-690.

[64] C. Ringle, M. Sarstedt, and D. Straub, "A Critical Look at the Use of PLS-SEM in MIS Quarterly," MIS Quarterly (MISQ), vol. 36, pp. i-xiv, 2012. 
[65] M. Wetzels, G. Odekerken-Schroder, and C. Van Oppen, "Using PLS Path Modelling for Assessing Hierarchical Construct Models: Guidelines and Empirical Illustration," MIS Quarterly, vol. 33, pp. 177-195, 2009.

[66] J.-M. Becker, K. Klein, and M. Wetzels, "Hierarchical latent variable models in PLS-SEM: guidelines for using reflective-formative type models," Long Range Planning, vol. 45, pp. 359-394, 2012.

[67] C. Fornell and D. F. Larcker, "Evaluating structural equation models with unobservable variables and measurement error," Journal of Marketing Research, vol. 18, pp. 39-50, 1981.

[68] R. B. Kline, Principles and Practice of Structural Equation Modeling vol. 3rd. New York: Guilford Press, 2011.

[69] J. Henseler, C. M. Ringle, and M. Sarstedt, "A new criterion for assessing discriminant validity in variance-based structural equation modeling," Journal of the Academy of Marketing Science, vol. 43, pp. 1-21, 2014.

[70] T. Brambor, W. R. Clark, and M. Golder, "Understanding interaction models: Improving empirical analyses," Political analysis, vol. 14, pp. 63-82, 2006.

[71] J. Henseler, T. K. Dijkstra, M. Sarstedt, C. M. Ringle, A. Diamantopoulos, D. W. Straub, et al., "Common Beliefs and Reality About PLS: Comments on Rönkkö and Evermann (2013)," Organizational Research Methods, vol. 17, pp. 182-209, April 1, 20142014.

[72] J. Henseler, G. Hubona, and P. A. Ray, "Using PLS path modeling in new technology research: updated guidelines," Industrial Management \& Data Systems, vol. 116, pp. 2-20, 2016.

[73] R. M. Baron and D. A. Kenny, "The moderator-mediator variable distinction in social psychology research: Conceptual, strategic, and statistical conciderations," Journal of Personality and Social Psychology, vol. 51, pp. 1173-1182, Dec 1986.

[74] T. Schmid, A.-K. Achleitner, M. Ampenberger, and C. Kaserer, "Family firms and R\&D behaviorNew evidence from a large-scale survey," Research Policy, vol. 43, pp. 233-244, 2014.

[75] K. V. Lins, P. Volpin, and H. F. Wagner, "Does family control matter? International evidence from the 2008-2009 financial crisis," Review of Financial Studies, vol. 26, pp. 2583-2619, 2013.

[76] B. Glaser and A. Strauss, "The discovery grounded theory: strategies for qualitative inquiry," Aldin, Chicago, 1967.

[77] M. B. Miles, A. M. Huberman, and J. Saldana, "Qualitative data analysis: A method sourcebook," CA, US: Sage Publications, 2014.

[78] F. Damanpour, "Organizational Innovation: A Meta-Analysis of Effects of Determinants and Moderators," Academy of Management Journal, vol. 34, pp. 555-590, 1991.

[79] W. Skinner, "The focused factory," Harvard Business Review, pp. 113-121, 1974.

[80] R. Verma, "Management science, theory of constraints optimized production technology and local optimization," Omega-International Journal of Management Science, vol. 25, pp. 189-200, Apr 1997.

[81] R. Amit and C. Zott, "Crafting Business Architecture: the Antecedents of Business Model Design," Strategic Entrepreneurship Journal, pp. 331-350, 2015.

[82] M. Sosna, R. N. Trevinyo-Rodriguez, and S. R. Velamuri, "Business Model Innovation through Trialand-Error Learning The Naturhouse Case," Long Range Planning, vol. 43, pp. 383-407, Apr-Jun 2010.

[83] F. Futterer, J. Schmidt, and S. Heidenreich, "Effectuation or causation as the key to corporate venture success? Investigating effects of entrepreneurial behaviors on business model innovation and venture performance," Long Range Planning, vol. 51, pp. 64-81, 2018/02/01/ 2018.

[84] R. Grewal and P. Tansuhaj, "Building organizational capabilities for managing economic crisis: The role of market orientation and strategic flexibility," Journal of marketing, vol. 65, pp. 67-80, 2001.

[85] S. Schneider and P. Spieth, "BUSINESS MODEL INNOVATION AND STRATEGIC FLEXIBILITY: INSIGHTS FROM AN EXPERIMENTAL RESEARCH DESIGN," International Journal of Innovation Management, vol. 18, p. 1440009, 2014/12/01 2014. 


\section{Appendix A}

\section{Overview of the Interview Process}

We solicited the interview informants from professional networks and screened them for people who had been involved with their firms' value capture innovation efforts. Their companies' demographics (industry and size), the informants' managerial positions, and the durations of the interviews, as well as interview questions, are provided below.

\begin{tabular}{|c|c|c|c|c|}
\hline $\begin{array}{l}\text { Interview } \\
\text { No. (I\#) }\end{array}$ & $\begin{array}{l}\text { Company } \\
\text { Business }\end{array}$ & $\begin{array}{c}\text { No. of } \\
\text { Employees }\end{array}$ & Informant's Position & $\begin{array}{c}\text { Interview } \\
\text { Duration } \\
\text { (minutes) }\end{array}$ \\
\hline 1 & CAD Software & 9,500 & $\begin{array}{l}\text { Industry Manager - } \\
\text { Manufacturing }\end{array}$ & 31 \\
\hline 2 & Car Manufacturer & 642,000 & Agile Product Owner & 35 \\
\hline 3 & Electronics & 400,500 & $\begin{array}{l}\text { Director Business } \\
\text { Model Innovation }\end{array}$ & 27 \\
\hline 4 & $\begin{array}{l}\text { Configuration } \\
\text { Software }\end{array}$ & 50 & $\begin{array}{l}\text { Head of Sales and } \\
\text { Business Development }\end{array}$ & 20 \\
\hline 5 & Bank & 22,000 & $\begin{array}{l}\text { Head of Innovation } \\
\text { Management and } \\
\text { Payment }\end{array}$ & 27 \\
\hline 6 & Solar Technology & 4,450 & $\begin{array}{l}\text { Manager of Service and } \\
\text { Business Model } \\
\text { Development }\end{array}$ & 31 \\
\hline 7 & $\begin{array}{l}\text { Computer } \\
\text { Technology }\end{array}$ & 107,300 & $\begin{array}{l}\text { General Manager, New } \\
\text { Business and } \\
\text { Innovation }\end{array}$ & 27 \\
\hline 8 & $\begin{array}{l}\text { Engineering } \\
\text { Technology }\end{array}$ & 2,598 & $\begin{array}{l}\text { Head of Strategy and } \\
\text { Business Development }\end{array}$ & 20 \\
\hline 9 & $\begin{array}{l}\text { Lighting } \\
\text { Technology }\end{array}$ & 500 & $\begin{array}{l}\text { Manager Business } \\
\text { Development }\end{array}$ & 27 \\
\hline 10 & $\begin{array}{l}\text { Logistics } \\
\text { Software } \\
\end{array}$ & 260 & $\begin{array}{l}\text { Head of Product and } \\
\text { Marketing }\end{array}$ & 18 \\
\hline 11 & Heating Devices & 12,100 & $\begin{array}{l}\text { Head of Innovation } \\
\text { Management }\end{array}$ & 13 \\
\hline & & & Total & 276 \\
\hline
\end{tabular}

Interview question \#1: To what degree did your company realize innovation in one of the two dimensions of the revenue model (revenues or cost)? Please briefly describe.

Interview question \#2: Did you experience any negative consequences of the changes in these two areas, which negatively affected your financial performance (at least on a mid-term basis).

a) Please describe particular situations in which you faced these negative consequences.

b) At which levels (e.g., individual employees, organizational culture, or structure) did these negative consequences occur?

c) How did these negative consequences particularly affect the financial performance? 


\section{Appendix B \\ Summary of the Key Findings and Insights from the Interviews}

\begin{tabular}{|c|c|}
\hline $\begin{array}{l}\text { Key Findings and } \\
\text { Insights }\end{array}$ & Illustrative Examples \\
\hline $\begin{array}{l}\text { Value capture } \\
\text { innovation as a systemic } \\
\text { change } \\
\text { - Potentially disrupt the } \\
\text { system } \\
\text { - Require mutual } \\
\text { adjustments from other } \\
\text { parts of the system, } \\
\text { otherwise resulting in } \\
\text { local optimization }\end{array}$ & $\begin{array}{l}\text { "OK, we now have sold licenses for } 15 \text { years. Everybody knows the process, and now we need } \\
\text { to come up with new documents for sales, for the internal team, for the billing and controlling } \\
\ldots \text { This is a cultural revolution for many of us, and it creates irritations and indeed leads to } \\
\text { losses." Head of Sales and Business Development, configuration software company - changing } \\
\text { from the licensing to subscription revenue model (I\#4) } \\
\text { "We ourselves always work in an ecosystem. In a business ecosystem, this does not help if you } \\
\text { as a company come up with a BMI [changing from perpetual licensing to a subscription model] } \\
\text { without considering the ecosystem... If you don't align your activities with the ecosystem, it } \\
\text { creates tension. There will indeed be changes, such as processes, incentives, and go-to-market } \\
\text { strategies. These changes create resistance in the ecosystem, which needs to be overcome. This } \\
\text { [overcoming the resistance] creates costs and maybe reduces the speed, which in turn reduces } \\
\text { revenue performance." Industry Manager - Manufacturing, CAD software company - } \\
\text { changing from the licensing to subscription revenue model (I\#1) }\end{array}$ \\
\hline $\begin{array}{l}\text { Loci of local } \\
\text { optimization problems } \\
\text { in the value capture } \\
\text { innovation } \\
\text { - Functions within the } \\
\text { firm } \\
\text { - People within the } \\
\text { firm } \\
\text { - Partners of the firm }\end{array}$ & 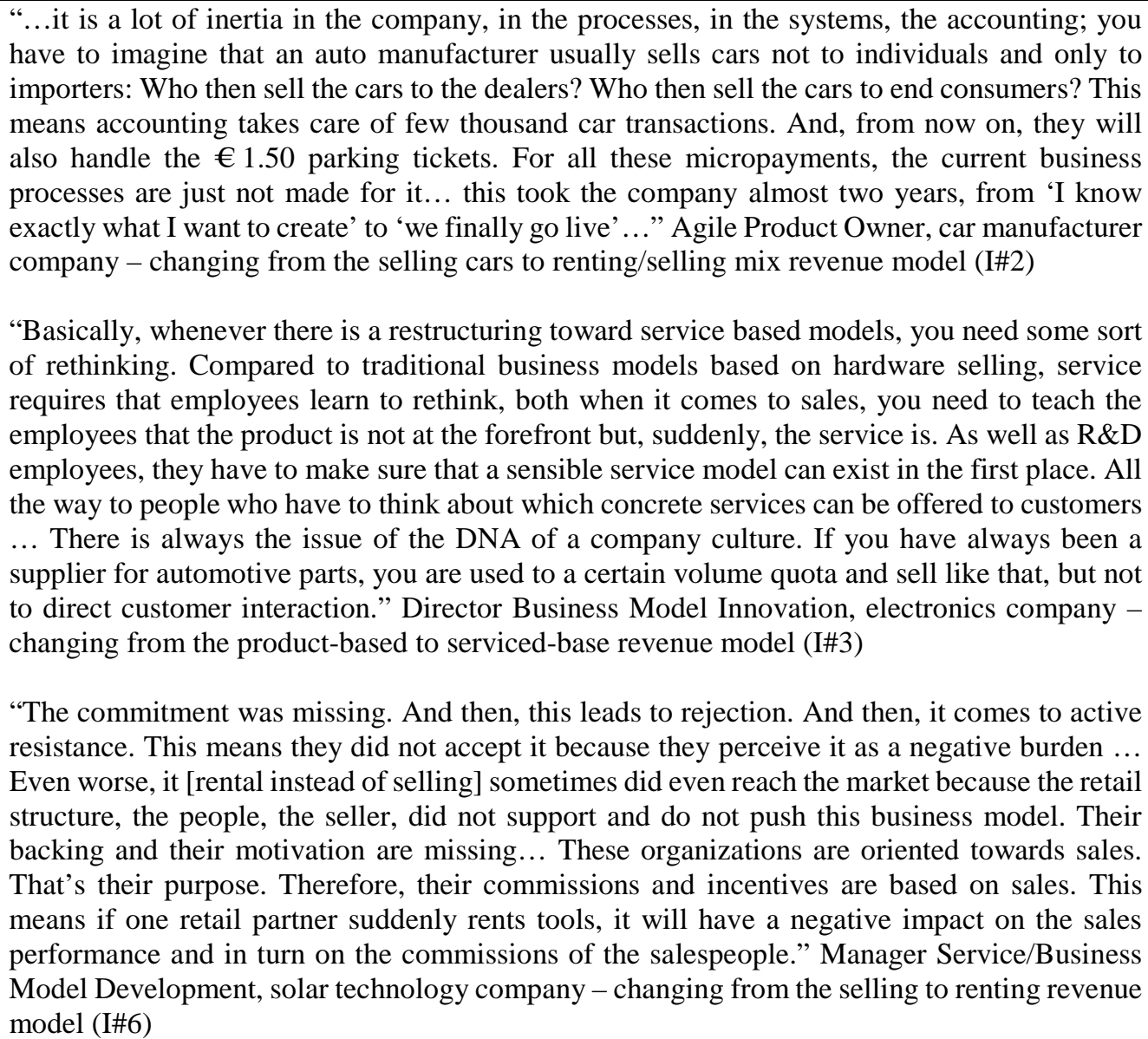 \\
\hline
\end{tabular}




\section{Figures \& Tables}

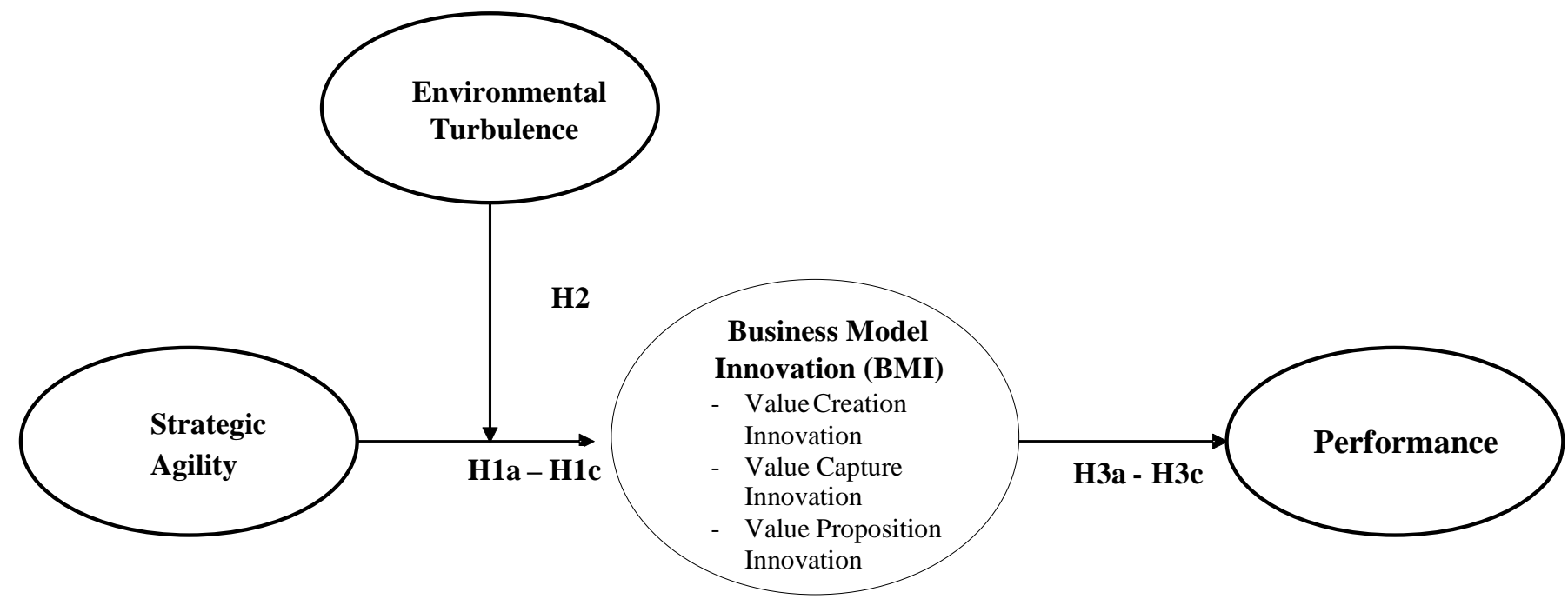

\section{H4 (mediation )}

Fig. 1: Conceptual model.
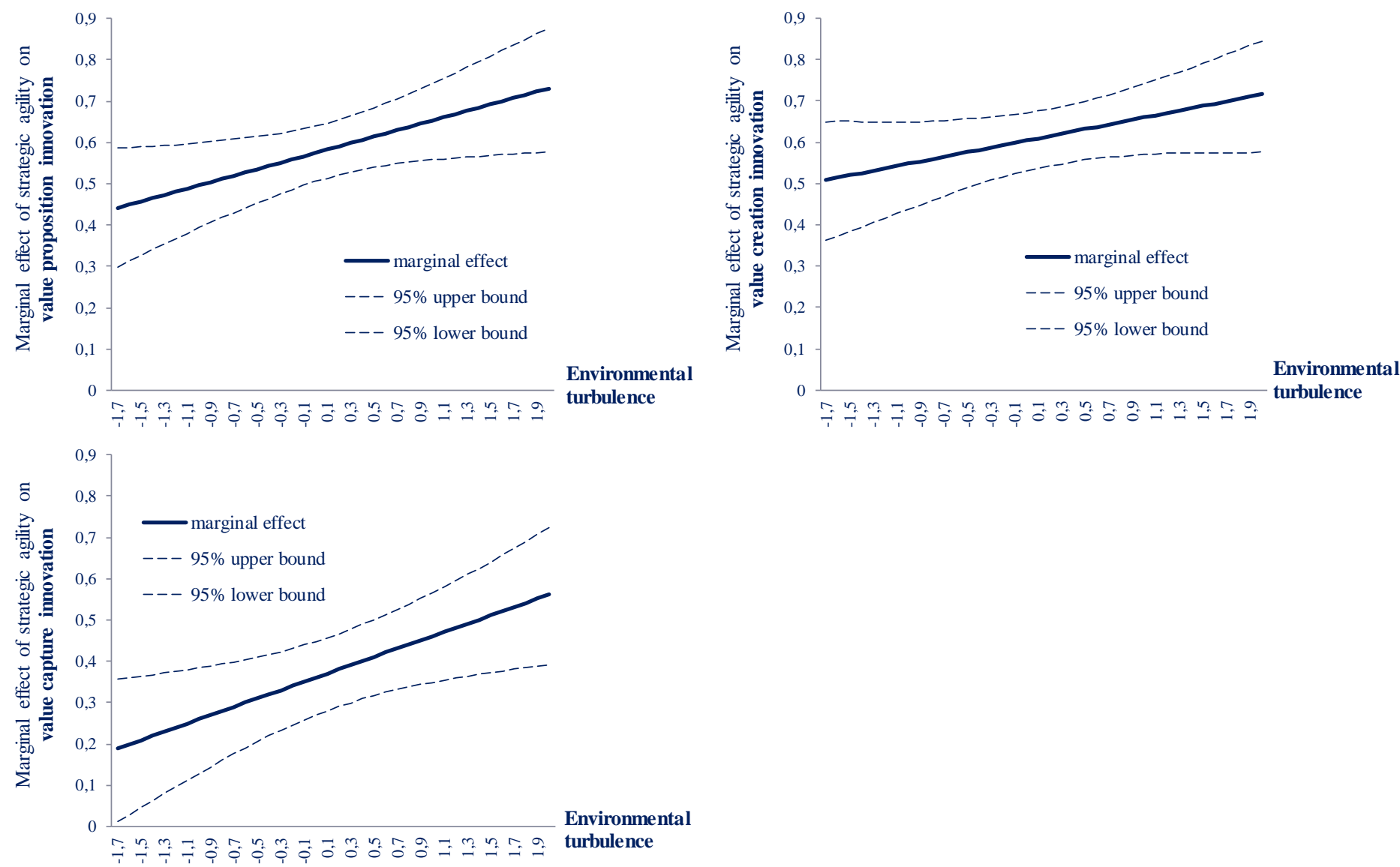

Fig. 2: Marginal effects. 
TABLE I

MEANS, STANDARD DEVIATIONS AND ZERO-ORDER CORRELATIONS

\begin{tabular}{|c|c|c|c|c|c|c|c|c|c|c|c|c|c|c|c|c|c|c|c|c|c|c|}
\hline \multicolumn{3}{|l|}{ Construct } & \multirow{2}{*}{\begin{tabular}{|l} 
Mean \\
3.29
\end{tabular}} & \multirow{2}{*}{\begin{tabular}{|l|}
$\begin{array}{l}\text { Std. } \\
\text { Dev. }\end{array}$ \\
0.82 \\
\end{tabular}} & \multirow{2}{*}{\begin{tabular}{|l|}
$\begin{array}{l}\text { Skew- } \\
\text { ness }\end{array}$ \\
-0.250 \\
\end{tabular}} & \multirow{2}{*}{\begin{tabular}{|l|}
$\begin{array}{l}\text { Kurto } \\
\text { sis }\end{array}$ \\
0.505 \\
\end{tabular}} & \multirow{2}{*}{\begin{tabular}{|l|} 
\\
$0.823^{a}$
\end{tabular}} & \multirow[t]{2}{*}{2} & \multirow[t]{2}{*}{3} & \multirow[t]{2}{*}{4} & \multirow[t]{2}{*}{5} & \multirow[t]{2}{*}{6} & \multirow[t]{2}{*}{7} & \multirow[t]{2}{*}{8} & \multirow[t]{2}{*}{9} & \multirow[t]{2}{*}{10} & \multirow[t]{2}{*}{11} & \multirow[t]{2}{*}{12} & \multirow[t]{2}{*}{13} & \multirow[t]{2}{*}{14} & \multirow[t]{2}{*}{15} & \multirow[t]{2}{*}{16} \\
\hline \multirow{3}{*}{$\begin{array}{l}\text { Strategic } \\
\text { agility }\end{array}$} & 1 & $\begin{array}{l}\text { Strategic } \\
\text { sensitivity }\end{array}$ & & & & & & & & & & & & & & & & & & & & \\
\hline & 2 & $\begin{array}{l}\text { Leadership } \\
\text { unity }\end{array}$ & 3.63 & 0.97 & -0.527 & 0.128 & \begin{tabular}{|l|}
$0.563 * *$ \\
$*$
\end{tabular} & 0.892 & & & & & & & & & & & & & & \\
\hline & 3 & $\begin{array}{l}\text { Resource } \\
\text { fluidity }\end{array}$ & 3.56 & 0.81 & -0.182 & -0.079 & \begin{tabular}{|l|}
$0.384 * *$ \\
$*$
\end{tabular} & $0.51^{* * *}$ & 0.808 & & & & & & & & & & & & & \\
\hline \multirow{4}{*}{$\begin{array}{l}\text { Value } \\
\text { creation } \\
\text { innovation }\end{array}$} & 4 & $\begin{array}{l}\text { New } \\
\text { capabilities }\end{array}$ & 3.76 & 0.79 & -0.426 & 0.061 & \begin{tabular}{|l|}
$0.428 * *$ \\
$*$
\end{tabular} & \begin{tabular}{|l|}
$0.462 * *$ \\
$*$
\end{tabular} & $\begin{array}{l}0.317^{* *} \\
*\end{array}$ & 0.811 & & & & & & & & & & & & \\
\hline & 5 & $\begin{array}{l}\text { New } \\
\text { technology }\end{array}$ & 3.80 & 0.80 & -0.383 & -0.500 & $\begin{array}{l}0.399 * * \\
*\end{array}$ & $\begin{array}{l}0.369 * * \\
*\end{array}$ & \begin{tabular}{|l|}
$0.288 * *$ \\
$*$
\end{tabular} & $\begin{array}{l}0.556^{* *} \\
*\end{array}$ & 0.829 & & & & & & & & & & & \\
\hline & 6 & \begin{tabular}{|l|} 
New \\
partnerships
\end{tabular} & 3.31 & 0.93 & -0.255 & -0.360 & \begin{tabular}{|l|}
$0.189 * *$ \\
$*$
\end{tabular} & $0.151^{* *}$ & $0.152 * *$ & \begin{tabular}{|l|}
$0.244 * *$ \\
$*$
\end{tabular} & \begin{tabular}{|l|}
$0.228^{* *}$ \\
$*$ \\
\end{tabular} & 0.804 & & & & & & & & & & \\
\hline & 7 & New processes & 3.64 & 0.84 & -0.416 & 0.070 & $\begin{array}{l}0.419 * * \\
*\end{array}$ & $\begin{array}{l}0.448 * * \\
*\end{array}$ & $\begin{array}{l}0.343 * * \\
*\end{array}$ & \begin{tabular}{|l|}
$0.584 * *$ \\
$*$
\end{tabular} & $\begin{array}{l}0.541 * * \\
*\end{array}$ & \begin{tabular}{|l|}
$0.308 * *$ \\
$*$
\end{tabular} & 0.833 & & & & & & & & & \\
\hline \multirow{2}{*}{$\begin{array}{l}\text { Value } \\
\text { capture } \\
\text { innovation }\end{array}$} & 8 & $\begin{array}{l}\text { New cost } \\
\text { structures }\end{array}$ & 2.91 & 0.98 & -0.454 & 0.050 & \begin{tabular}{|l|}
$\begin{array}{l}0.414 * * \\
*\end{array}$ \\
\end{tabular} & $0.39 * * *$ & $0.33 * * *$ & $\begin{array}{l}0.463 * * \\
*\end{array}$ & \begin{tabular}{|l|}
$0.478 * *$ \\
$*$
\end{tabular} & $0.2 * * *$ & \begin{tabular}{|l|}
$\begin{array}{l}0.409 * * \\
*\end{array}$ \\
\end{tabular} & 0.807 & & & & & & & & \\
\hline & 9 & $\begin{array}{l}\text { New revenue } \\
\text { models }\end{array}$ & 3.64 & 0.84 & -0.081 & -0.532 & \begin{tabular}{|l|}
$0.351^{* *}$ \\
$*$
\end{tabular} & \begin{tabular}{|l|}
$0.231 * *$ \\
$*$
\end{tabular} & $\begin{array}{l}0.238 * * \\
*\end{array}$ & \begin{tabular}{|l|}
$0.205^{* *}$ \\
$*$
\end{tabular} & \begin{tabular}{|l|}
$0.173 * *$ \\
$*$
\end{tabular} & $0.39 * * *$ & \begin{tabular}{|l|}
$0.256 * *$ \\
$*$
\end{tabular} & \begin{tabular}{|l|}
$0.236 * *$ \\
$*$
\end{tabular} & 0.859 & & & & & & & \\
\hline \multirow{4}{*}{$\begin{array}{l}\text { Value } \\
\text { proposition } \\
\text { innovation }\end{array}$} & 10 & New offerings & 3.85 & 0.75 & -0.307 & -0.443 & $\begin{array}{l}0.367 * * \\
*\end{array}$ & $\begin{array}{l}0.253 * * \\
*\end{array}$ & $\begin{array}{l}0.191 * * \\
*\end{array}$ & \begin{tabular}{|l|}
$0.357 * *$ \\
$*$
\end{tabular} & \begin{tabular}{|l|}
$0.325 * *$ \\
$*$
\end{tabular} & \begin{tabular}{|l|}
$0.329 * *$ \\
$*$
\end{tabular} & \begin{tabular}{|l|}
$0.408 * *$ \\
$*$
\end{tabular} & \begin{tabular}{|l|}
$0.341^{* *}$ \\
$*$
\end{tabular} & \begin{tabular}{|l|}
$0.488 * *$ \\
$*$
\end{tabular} & 0.816 & & & & & & \\
\hline & 11 & \begin{tabular}{|l|}
$\begin{array}{l}\text { New } \\
\text { customers and } \\
\text { markets }\end{array}$ \\
\end{tabular} & 3.69 & 0.84 & 0.001 & -0.314 & $\begin{array}{l}0.456 * * \\
*\end{array}$ & $\begin{array}{l}0.335 * * \\
*\end{array}$ & $\begin{array}{l}0.334 * * \\
*\end{array}$ & $\begin{array}{l}0.381 * * \\
*\end{array}$ & $\begin{array}{l}0.373 * * \\
*\end{array}$ & $0.39 * * *$ & $0.41^{* * *}$ & $\begin{array}{l}0.539 * * \\
*\end{array}$ & $\begin{array}{l}0.427 * * \\
*\end{array}$ & $\begin{array}{l}0.439 * * \\
*\end{array}$ & 0.867 & & & & & \\
\hline & 12 & New channels & 2.92 & 0.98 & -0.351 & -0.134 & $\begin{array}{l}0.273 * * \\
*\end{array}$ & $0.153 * *$ & $0.128 * *$ & \begin{tabular}{|l|}
$0.266 * *$ \\
$*$
\end{tabular} & \begin{tabular}{|l|}
$0.279 * *$ \\
$*$
\end{tabular} & $0.4^{* * *}$ & \begin{tabular}{|l|}
$0.231 * *$ \\
$*$
\end{tabular} & $\begin{array}{l}0.251 * * \\
*\end{array}$ & \begin{tabular}{|l|}
$0.396 * *$ \\
$*$
\end{tabular} & \begin{tabular}{|l|}
$0.482 * *$ \\
$*$
\end{tabular} & \begin{tabular}{|l|}
$0.369 * *$ \\
$*$
\end{tabular} & 0.745 & & & & \\
\hline & 13 & \begin{tabular}{|l|} 
New customer \\
relationships
\end{tabular} & 3.50 & 0.90 & -0.315 & -0.224 & \begin{tabular}{|l|}
$0.307 * *$ \\
$*$
\end{tabular} & \begin{tabular}{|l|}
$0.258 * *$ \\
$*$
\end{tabular} & \begin{tabular}{|l|}
$0.241 * *$ \\
$*$
\end{tabular} & \begin{tabular}{|l|}
$0.308 * *$ \\
$*$
\end{tabular} & \begin{tabular}{|l|}
$0.242 * *$ \\
$*$
\end{tabular} & \begin{tabular}{|l|}
$0.345 * *$ \\
$*$
\end{tabular} & \begin{tabular}{|l|}
$0.448 * *$ \\
$*$
\end{tabular} & \begin{tabular}{|l|}
$0.249 * *$ \\
$*$
\end{tabular} & \begin{tabular}{|l|}
$0.344 * *$ \\
$*$
\end{tabular} & \begin{tabular}{|l|}
$0.395 * *$ \\
$*$
\end{tabular} & \begin{tabular}{|l|}
$0.412 * *$ \\
$*$
\end{tabular} & \begin{tabular}{|l|}
$0.246 * *$ \\
$*$
\end{tabular} & 0.791 & & & \\
\hline Performance & 14 & Performance & 3.42 & 0.73 & -0.076 & 0.851 & \begin{tabular}{|l|}
$0.418 * *$ \\
$*$
\end{tabular} & $\begin{array}{l}0.356 * * \\
*\end{array}$ & $\begin{array}{l}0.321 * * \\
*\end{array}$ & \begin{tabular}{|l|}
$0.368 * *$ \\
$*$
\end{tabular} & $\begin{array}{l}0.379 * * \\
*\end{array}$ & $0.145^{* *}$ & \begin{tabular}{|l|}
$0.366 * *$ \\
$*$
\end{tabular} & $0.32 * * *$ & \begin{tabular}{|l|}
$0.198 * *$ \\
$*$
\end{tabular} & \begin{tabular}{|l|}
$0.232 * *$ \\
$*$
\end{tabular} & \begin{tabular}{|l|}
$0.294^{* *}$ \\
$*$
\end{tabular} & $0.156^{* *}$ & $\begin{array}{l}0.171^{* *} \\
*\end{array}$ & 0.804 & & \\
\hline \multirow[b]{2}{*}{ Controls } & 15 & $\begin{array}{l}\text { Environmental } \\
\text { turbulence }\end{array}$ & 2.82 & 0.87 & 0.313 & -0.182 & $\begin{array}{l}0.225^{* *} \\
*\end{array}$ & 0.09 & 0.026 & $0.114 *$ & $0.136^{* *}$ & $\begin{array}{l}0.239 * * \\
*\end{array}$ & $0.113^{*}$ & $0.116^{*}$ & $\begin{array}{l}0.222 * * \\
*\end{array}$ & \begin{tabular}{|l|}
$0.164 * *$ \\
$*$
\end{tabular} & $0.142 * *$ & $\begin{array}{l}0.257 * * \\
*\end{array}$ & $0.141^{* *}$ & $0.105^{*}$ & 0.781 & \\
\hline & 16 & \begin{tabular}{|l|} 
No. \\
Employees \\
(ln)b \\
\end{tabular} & 4.25 & 1.78 & 0.774 & 1.310 & -0.003 & $-0.14 * *$ & -0.036 & 0.04 & 0.045 & -0.037 & $0.105^{*}$ & -0.034 & 0.015 & 0.05 & 0.041 & 0.065 & $0.106^{*}$ & $0.155^{* *}$ & 0.077 & 1 \\
\hline
\end{tabular}




\section{TABLE II}

EVALUATION OF THE OUTER REFLECTIVE MEASUREMENT MODEL

\begin{tabular}{|c|c|c|c|}
\hline Construct & Measurement Item & Loading & CR \\
\hline \multirow{3}{*}{$\begin{array}{c}\text { New } \\
\text { capabilities } \\
\text { Clauss (2016) }\end{array}$} & Our employees constantly receive trainings in order to develop new competences. & 0.846 & \multirow{3}{*}{0.852} \\
\hline & $\begin{array}{l}\text { Relative to our direct competitors, our employees have very up-to-date knowledge and } \\
\text { capabilities. }\end{array}$ & 0.783 & \\
\hline & $\begin{array}{l}\text { We permanently reflect which new competencies need to be established in order to adapt to } \\
\text { changing market requirements. }\end{array}$ & 0.805 & \\
\hline \multirow{3}{*}{$\begin{array}{c}\text { New } \\
\text { technologies } \\
\text { Clauss (2016) }\end{array}$} & We keep the technical resources of our company up-to-date. & 0.839 & \multirow{3}{*}{0.868} \\
\hline & Relative to our competitors our technical equipment is very innovative. & 0.817 & \\
\hline & $\begin{array}{l}\text { We regularly utilize new technical opportunities in order to extend our product and service } \\
\text { portfolio. }\end{array}$ & 0.830 & \\
\hline \multirow{4}{*}{\begin{tabular}{l}
\multicolumn{1}{c}{ New } \\
partnerships \\
Clauss (2016)
\end{tabular}} & We are constantly searching for new collaboration partners. & 0.765 & \multirow{4}{*}{0.879} \\
\hline & We regularly utilize opportunities that arise from integration of new partners into our processes. & 0.888 & \\
\hline & We regularly ask ourselves if we could benefit from outsourcing. & 0.708 & \\
\hline & New collaboration partners regularly help us to further develop our business model. & 0.844 & \\
\hline \multirow{3}{*}{$\begin{array}{l}\text { New processes } \\
\text { Clauss (2016) }\end{array}$} & We were recently able to significantly improve our internal processes. & 0.779 & \multirow{3}{*}{0.872} \\
\hline & We utilize innovative procedures and processes during manufacturing of our products. & 0.866 & \\
\hline & Existing processes are regularly assessed and significantly changed if needed. & 0.851 & \\
\hline \multirow{3}{*}{$\begin{array}{l}\text { New offerings } \\
\text { Clauss (2016) }\end{array}$} & We regularly address new, unmet customer needs. & 0.717 & \multirow{3}{*}{0.848} \\
\hline & Our products or services are very innovative in relation to our competitors. & 0.870 & \\
\hline & Our products or services regularly solve customer needs, which were not solved by competitors. & 0.827 & \\
\hline \multirow{3}{*}{$\begin{array}{c}\text { New customers } \\
\text { and markets } \\
\text { Clauss (2016) }\end{array}$} & We regularly take opportunities which arise in new or growing markets. & 0.840 & \multirow{3}{*}{0.894} \\
\hline & We regularly address new, unserved market segments. & 0.904 & \\
\hline & We are constantly seeking new customer segments and markets for our products and services. & 0.831 & \\
\hline \multirow{3}{*}{$\begin{array}{l}\text { New channels } \\
\text { Clauss (2016) }\end{array}$} & We regularly utilize new distribution channels for our products and services. & 0.796 & \multirow{3}{*}{0.856} \\
\hline & Constant changes of our channels led to improved efficiency of our channel functions. & 0.768 & \\
\hline & We consistently changed our portfolio of distribution channels. & 0.880 & \\
\hline \multirow{3}{*}{$\begin{array}{l}\text { New customer } \\
\text { relationships } \\
\text { Clauss (2016) } \\
\end{array}$} & We try to increase customer retention by new service offerings. & 0.885 & \multirow{3}{*}{0.901} \\
\hline & We emphasize innovative/ modern actions to increase customer retention (e.g. CRM). & 0.890 & \\
\hline & We recently took many actions in order to strengthen customer relationships. & 0.825 & \\
\hline \multirow{3}{*}{$\begin{array}{l}\text { New Revenue } \\
\text { Models } \\
\text { Clauss (2016) }\end{array}$} & We recently developed new revenue opportunities (e.g. additional sales, cross selling). & 0.773 & \multirow{3}{*}{0.789} \\
\hline & $\begin{array}{l}\text { We increasingly offer integrated services (e.g. maintenance contracts) in order to realize long- } \\
\text { term financial returns. }\end{array}$ & 0.723 & \\
\hline & $\begin{array}{l}\text { We recently complemented or replaced one-time transaction one-time transaction revenues (e.g. } \\
\text { single sales) with long-term recurring revenue models (e.g. leasing). }\end{array}$ & 0.740 & \\
\hline \multirow{4}{*}{$\begin{array}{c}\text { New cost } \\
\text { structures } \\
\text { Clauss (2016) }\end{array}$} & We regularly reflect our price-quantity strategy. & 0.718 & \multirow{4}{*}{0.869} \\
\hline & We actively seek for opportunities to save manufacturing costs. & 0.760 & \\
\hline & $\begin{array}{l}\text { Our production costs are constantly examined and if necessary amended according to market } \\
\text { prices. }\end{array}$ & 0.865 & \\
\hline & We utilize opportunities, which arise through price differentiation. & 0.815 & \\
\hline \multirow{3}{*}{$\begin{array}{c}\text { Strategic } \\
\text { Sensitivity } \\
\text { Hock et al. } \\
\text { (2016) }\end{array}$} & $\begin{array}{l}\text { We are very sensitive for external changes (regarding customers, competitors, technologies etc.) } \\
\text { and integrate these into strategic planning of our company. }\end{array}$ & 0.804 & \multirow{3}{*}{0.863} \\
\hline & We utilize different mechanisms to become aware of strategic developments early. & 0.857 & \\
\hline & $\begin{array}{l}\text { Requirements for strategic adaptations are communicated fast and comprehensively through the } \\
\text { organization. }\end{array}$ & 0.808 & \\
\hline Leadership & Our top management is able to make bold and fast strategic decisions. & 0.896 & \\
\hline & Our management collaborates for strategic decisions. & 0.930 & \\
\hline $\begin{array}{l}\text { Hock et al. } \\
\text { (2016) }\end{array}$ & $\begin{array}{l}\text { Strategic questions are collectively solved by our management without being bogged down in } \\
\text { top-level 'win-lose' politics. }\end{array}$ & 0.850 & 0.9 \\
\hline Resource & We are able to reallocate and utilize capital resources fluidly. & 0.772 & \\
\hline & Our people and their competencies are highly mobile within our organization. & 0.810 & 0.849 \\
\hline $\begin{array}{l}\text { Hock et al. } \\
\text { (2016) }\end{array}$ & Our organizational structure allows for flexible redeployment of our resources. & 0.840 & \\
\hline & Relative to our competitors our financial performance was much better. & 0.768 & \\
\hline performance & Relative to our competitors, the market share of our organization was much better. & 0.809 & \\
\hline Venkatraman/ & Relative to our competitors, the sales growth of our organization was much better. & 0.849 & 0.901 \\
\hline Ramanujam & Relative to our competitors, the product development of our organization was much better. & 0.788 & \\
\hline (1986) & Relative to our competitors, the development of our organization was much better. & 0.802 & \\
\hline Environmental & The actions of competitors in our major markets were changing quite rapidly. & 0.748 & \\
\hline turbulence & Technological changes in our industry were rapid and unpredictable. & 0.877 & \\
\hline Jaworski/ Kohli & Customers' product preferences changed quite rapidly. & 0.833 & 0.860 \\
\hline (1993) & Changes in customers' needs were quite unpredictable. & 0.643 & \\
\hline
\end{tabular}


TABLE III

EVALUATION OF THE INNER FORMATIVE MEASUREMENT MODEL

\begin{tabular}{|c|l|l|}
\hline Construct/Item & Path weight & VIF \\
\hline Value proposition innovation & & \\
\hline New offerings & $0.504^{* * *}(0.078)$ & 1.401 \\
\hline New customers and markets & $0.299^{* *}(0.104)$ & 1.456 \\
\hline New channels & $0.143(0.094)$ & 1.489 \\
\hline New customer relationships & $0.364^{* * *}(0.093)$ & 1.652 \\
\hline Value creation innovation & & \\
\hline New capabilities & $0.431^{* * *}(0.079)$ & 1.676 \\
\hline New technologies & $0.394^{* * *}(0.080)$ & 1.497 \\
\hline New partnerships & $0.074(0.084)$ & 1.119 \\
\hline New processes & $0.348^{* * *}(0.087)$ & 1.752 \\
\hline Value capture innovation & & \\
\hline New cost structures & $0.654^{* * *}(0.113)$ & 1.078 \\
\hline New revenue models & $0.601^{* * *}(0.123)$ & 1.078 \\
\hline Strategic Agility & & \\
\hline Strategic sensitivity & $0.631^{* * *}(0.086)$ & 1.569 \\
\hline Collective commitment & $0.302^{* *}(0.103)$ & 1.768 \\
\hline Resource fluidity & $0.266^{* *}(0.086)$ & 1.372 \\
\hline
\end{tabular}

$\dagger \mathrm{p}<0.100,{ }^{*} \mathrm{p}<0.050,{ }^{* *} \mathrm{p}<0.010,{ }^{* * *} \mathrm{p}<0.001$, values in parentheses show standard errors

TABLE V

MEDIATION TEST

\begin{tabular}{|c|c|c|c|c|}
\hline & $\begin{array}{l}\text { Standard } \\
\text { Effect }\end{array}$ & t-Value & \multicolumn{2}{|c|}{ 95\% Confidence Interval } \\
\hline Specific Indirect effects & & & Low Limit & Upper Limit \\
\hline $\begin{array}{c}\text { Strategic Agility } \rightarrow \text { Value Creation } \\
\text { Innovation } \rightarrow \text { Performance }\end{array}$ & 0.128 & 2.933 & 0.045 & 0.215 \\
\hline $\begin{array}{c}\text { Strategic Agility } \rightarrow \text { Value Capture } \\
\text { Innovation } \rightarrow \text { Performance }\end{array}$ & -0.043 & 1.763 & -0.096 & 0.002 \\
\hline $\begin{array}{c}\text { Strategic Agility } \rightarrow \text { Value } \\
\text { Proposition Innovation } \rightarrow \\
\text { Performance }\end{array}$ & 0.081 & 1.961 & 0.003 & \\
\hline Total Indirect effect & & & & $\mathbf{0 . 2 7 4}$ \\
\hline $\begin{array}{c}\text { Strategic Agility } \rightarrow \text { Business Model } \\
\text { Innovation } \rightarrow \text { Performance }\end{array}$ & $\mathbf{0 . 1 6 6}$ & $\mathbf{3 . 4 1 2}$ & $\mathbf{0 . 0 8 1}$ & \\
\hline
\end{tabular}


TABLE IV

HYPOTHESIS TEST AND MODEL FIT

\begin{tabular}{|c|c|c|c|c|c|c|c|c|c|c|c|}
\hline & \multicolumn{3}{|c|}{$\begin{array}{c}\text { DV: Value Proposition } \\
\text { Innovation }\end{array}$} & \multicolumn{3}{|c|}{$\begin{array}{c}\text { DV: Value Creation } \\
\text { Innovation }\end{array}$} & \multicolumn{3}{|c|}{ DV: Value Capture Innovation } & \multicolumn{2}{|c|}{$\begin{array}{c}\text { DV: Firm } \\
\text { Performance }\end{array}$} \\
\hline & $\begin{array}{l}\text { Model 1 } \\
\text { (controls) }\end{array}$ & $\begin{array}{l}\text { Model } 2 \\
\text { (Main } \\
\text { effects) }\end{array}$ & $\begin{array}{c}\text { Model 3 } \\
\text { (Interaction } \\
\text { effects) }\end{array}$ & $\begin{array}{r}\text { Model } 1 \\
\text { (controls) }\end{array}$ & $\begin{array}{l}\text { Model } 2 \\
\text { (Main } \\
\text { effects) }\end{array}$ & $\begin{array}{l}\text { Model 3 } \\
\text { (Interacti } \\
\text { on } \\
\text { effects) }\end{array}$ & $\begin{array}{c}\text { Model 1 } \\
\text { (controls) }\end{array}$ & $\begin{array}{c}\text { Model } \\
2 \\
\text { (Main } \\
\text { effects) }\end{array}$ & \begin{tabular}{l}
\multicolumn{1}{c}{ Model 3 } \\
(Interaction \\
effects)
\end{tabular} & $\begin{array}{l}\text { Model 1 } \\
\text { (controls) }\end{array}$ & $\begin{array}{c}\text { Model } \\
2+3 \\
\text { (Main } \\
\text { effects) }\end{array}$ \\
\hline \multicolumn{12}{|l|}{ Controls } \\
\hline $\begin{array}{l}\text { Firm Size } \\
\text { (Log. of } \\
\text { Employees) }\end{array}$ & $\begin{array}{l}0.062 \\
(0.058)\end{array}$ & $\begin{array}{l}0.034 \\
(0.033)\end{array}$ & $\begin{array}{l}0.030 \\
(0.031)\end{array}$ & $\begin{array}{l}0.156^{*} \\
(0.076)\end{array}$ & $\begin{array}{l}0.111^{*} \\
(0.048)\end{array}$ & $\begin{array}{l}0.108 * \\
(0.047)\end{array}$ & $\begin{array}{l}0.136 * \\
(0.059)\end{array}$ & $\begin{array}{l}0.14 * \\
(0.057)\end{array}$ & $\begin{array}{l}0.135^{*} \\
(0.057)\end{array}$ & $\begin{array}{l}0.184 * * * \\
(0.046)\end{array}$ & $\begin{array}{l}0.188 * * \\
*(0.046)\end{array}$ \\
\hline $\begin{array}{l}\text { Industry = } \\
\text { auto }\end{array}$ & $\begin{array}{l}0.021 \\
(0.055) \\
\end{array}$ & $\begin{array}{l}0.028 \\
(0.034) \\
\end{array}$ & $\begin{array}{l}0.020 \\
(0.031) \\
\end{array}$ & $\begin{array}{l}-0.008 \\
(0.065) \\
\end{array}$ & $\begin{array}{l}0.028 \\
(0.025) \\
\end{array}$ & $\begin{array}{l}0.022 \\
(0.024) \\
\end{array}$ & $\begin{array}{l}0.003 \\
(0.047) \\
\end{array}$ & $\begin{array}{l}-0.004 \\
(0.036) \\
\end{array}$ & $\begin{array}{l}-0.014 \\
(0.035) \\
\end{array}$ & $\begin{array}{l}-0.021 \\
(0.041) \\
\end{array}$ & $\begin{array}{l}-0.049 \\
(0.039) \\
\end{array}$ \\
\hline $\begin{array}{l}\text { Industry = } \\
\text { engineering }\end{array}$ & $\begin{array}{l}-0.086 \\
(0.064) \\
\end{array}$ & $\begin{array}{l}0.015 \\
(0.034) \\
\end{array}$ & $\begin{array}{l}0.007 \\
(0.033) \\
\end{array}$ & $\begin{array}{l}0.048 \\
(0.075) \\
\end{array}$ & $\begin{array}{l}-0.006 \\
(0.027) \\
\end{array}$ & $\begin{array}{l}-0.011 \\
(0.028) \\
\end{array}$ & $\begin{array}{l}0.014 \\
(0.039) \\
\end{array}$ & $\begin{array}{l}0.021 \\
(0.032) \\
\end{array}$ & $\begin{array}{l}0.012 \\
(0.03) \\
\end{array}$ & $\begin{array}{l}-0.057 \\
(0.047) \\
\end{array}$ & $\begin{array}{l}-0.062 \\
(0.042) \\
\end{array}$ \\
\hline $\begin{array}{l}\text { Industry = } \\
\text { electronics }\end{array}$ & $\begin{array}{l}-0.054 \\
(0.06) \\
\end{array}$ & $\begin{array}{l}-0.011 \\
(0.03) \\
\end{array}$ & $\begin{array}{l}-0.008 \\
(0.03) \\
\end{array}$ & $\begin{array}{l}0.009 \\
(0.051) \\
\end{array}$ & $\begin{array}{l}-0.048 \\
(0.041) \\
\end{array}$ & $\begin{array}{l}-0.046 \\
(0.039)\end{array}$ & $\begin{array}{l}-0.048 \\
(0.049) \\
\end{array}$ & $\begin{array}{l}-0.082 \\
(0.050)\end{array}$ & $\begin{array}{l}-0.078 \\
(0.049) \\
\end{array}$ & $\begin{array}{l}-0.027 \\
(0.042) \\
\end{array}$ & $\begin{array}{l}-0.055 \\
(0.043) \\
\end{array}$ \\
\hline \multicolumn{12}{|l|}{$\begin{array}{l}\text { Independent } \\
\text { Variables } \\
\end{array}$} \\
\hline $\begin{array}{l}\text { Strategic } \\
\text { Agility }\end{array}$ & & $\begin{array}{l}0.573 * * \\
*(0.041)\end{array}$ & $\begin{array}{l}0.570 * * * \\
(0.041)\end{array}$ & & $\begin{array}{l}0.604 * * \\
*(0.043)\end{array}$ & $\begin{array}{l}0.601 * * * \\
(0.043)\end{array}$ & & $\begin{array}{l}0.359 * \\
* * \\
(0.055)\end{array}$ & $\begin{array}{c}0.354^{* * *} \\
(0.055)\end{array}$ & & \\
\hline $\begin{array}{l}\text { Environmenta } \\
\text { l turbulence }\end{array}$ & & $\begin{array}{l}0.095^{*} \\
(0.048)\end{array}$ & $\begin{array}{l}0.083 \dagger \\
(0.048)\end{array}$ & & $\begin{array}{l}0.089 \dagger \\
(0.046)\end{array}$ & $\begin{array}{l}0.081 \dagger \\
(0.045)\end{array}$ & & $\begin{array}{l}0.195 * \\
* * \\
(0.058) \\
\end{array}$ & $\begin{array}{l}0.18^{* *} \\
(0.06)\end{array}$ & & \\
\hline $\begin{array}{l}\text { Value } \\
\text { proposition } \\
\text { Innovation } \\
\end{array}$ & & & & & & & & & & & $\begin{array}{l}0.142 \dagger \\
(0.075)\end{array}$ \\
\hline $\begin{array}{l}\text { Value } \\
\text { creation } \\
\text { Innovation } \\
\end{array}$ & & & & & & & & & & & $\begin{array}{l}0.213^{* *} \\
(0.07)\end{array}$ \\
\hline $\begin{array}{l}\text { Value capture } \\
\text { Innovation }\end{array}$ & & & & & & & & & & & $\begin{array}{l}-0.121^{*} \\
(0.061)\end{array}$ \\
\hline $\begin{array}{l}\text { Strategic } \\
\text { Agility X } \\
\text { Environmenta } \\
\text { I turbulence } \\
\end{array}$ & & & $\begin{array}{l}0.083^{*} \\
(0.04)\end{array}$ & & & $\begin{array}{l}0.060 \dagger \\
(0.035)\end{array}$ & & & $\begin{array}{l}0.106 * \\
(0.048)\end{array}$ & & \\
\hline $\mathrm{R}^{2}$ & 0.013 & 0.358 & 0.367 & 0.025 & 0.400 & 0.405 & 0.020 & 0.209 & 0.223 & 0.037 & 0.320 \\
\hline$\Delta \mathrm{R}^{2}$ & & $0.345^{* *}$ & 0.009 & & $\begin{array}{l}0.375^{* *} \\
*\end{array}$ & 0.005 & & $\begin{array}{l}0.207 * \\
*\end{array}$ & 0.016 & & $0.283^{* *}$ \\
\hline Adjusted $\mathrm{R}^{2}$ & 0.001 & 0.346 & 0.353 & 0.014 & 0.389 & 0.392 & 0.008 & 0.195 & 0.207 & 0.026 & 0.302 \\
\hline$\Delta$ adjusted $\mathrm{R}^{2}$ & & $\begin{array}{l}0.345^{* *} \\
*\end{array}$ & 0.007 & & $\begin{array}{l}0.375^{* *} \\
*\end{array}$ & 0.003 & & $\begin{array}{l}0.187 * \\
*\end{array}$ & 0.012 & & $0.276 * *$ \\
\hline $\mathrm{Q}^{2}$ & 0.016 & 0.177 & 0.181 & 0.011 & 0.202 & 0.204 & 0.002 & 0.105 & 0.110 & 0.019 & 0.174 \\
\hline$\Delta \mathrm{Q}^{2}$ & & 0.161 & 0.004 & & 0.191 & 0.002 & & 0.103 & 0.005 & & 0.155 \\
\hline
\end{tabular}

$\dagger p<0.10, * p<0.05, * * p<0.01, * * * p<0.001$, values in parentheses show standard errors, Standardized Root Mean Square Residual $(S R M R): M 1=0.194, M 2=0.077, M 3=0.076$ 